\title{
Construction of Optically Active Isotwistanes and Aminocyclitols Using Chiral Cyclohexadiene as a Common Intermediate
}

\author{
Shinji Harada, ${ }^{a, b}$ Kexin Li, ${ }^{a}$ Ryuto Kino, ${ }^{a}$ Takuya Takeda, ${ }^{a}$ Chia-Hsien Wu, ${ }^{a, c}$ \\ Shiharu Hiraoka, ${ }^{a}$ and Atsushi Nishida*,a,b \\ ${ }^{a}$ Graduate School of Pharmaceutical Sciences, Chiba University; 1-8-1 Inohana, Chuo-ku, Chiba 260-8675, Japan: \\ ${ }^{b}$ Molecular Chirality Research Center, Chiba University; 1-33 Yayoi-cho, Inage-ku, Chiba 263-8522, Japan: and \\ ${ }^{c}$ Department of Chemistry, National Tsing Hua University; 101, Sec 2, Kuang-Fu Rd., Hsinchu 30013, Taiwan. \\ Received May 29, 2016; accepted July 9, 2016; advance publication released online July 22, 2016
}

We have developed a new method for synthesizing chiral isotwistane and homoisotwistane skeletons as well as aminocyclitols in a highly stereoselective manner. These results were achieved through the use of a common intermediate, which was derived from the ytterbium-catalyzed asymmetric Diels-Alder reaction of Danishefsky diene. Alder

Key words isotwistane; homoisotwistane; aminocyclitol; Diels-Alder; asymmetric catalysis; hetero-Diels-

Many biologically active compounds possess a cyclic skeleton with center chirality in their structure. Therefore, the stereoselective synthesis of optically active carbon frameworks is in high demand for synthetic and medicinal chemists. The Diels-Alder reaction has been widely used for this purpose to construct six-membered carbocycles, and the catalytic and enantioselective variant of this reaction has been studied for decades. ${ }^{1)}$ Our group reported the first example of the catalytic and asymmetric Diels-Alder reaction of Danishefsky diene $(\mathbf{1})^{2,3)}$ (Chart 1). Functionalized cyclohexene 3 was obtained in optically pure form, and $\mathbf{3}$ could be transformed to cyclohexenone $\mathbf{4}$ in quantitative yield. Both functionalized compounds could be potential synthetic intermediates, and we have previously demonstrated the synthetic utility of this reaction. ${ }^{4-7)}$

In the present study, silyloxy-substituted cyclohexadiene 7 derived from 4 was shown to be a key intermediate for two types of synthetically useful chiral building blocks, i.e., the tricyclo[4.3.1.0 $\left.0^{3,7}\right]$ decane (isotwistane $8, n=1$ ) and tricyclo[5.3.1. $\left.0^{3,8}\right]$ undecane (homoisotwistane $8, n=2$ ) skeletons via the intramolecular Diels-Alder reaction, and aminocyclitol 10 via the intermolecular hetero-Diels-Alder reaction with nitrosobenzene (Chart 2).

\section{Results and Discussion}

Construction of Isotwistane and Homoisotwistane Skeletons Isotwistane is an all-carbon tricyclic compound, and its structural motif is found in natural products such as pupukeananes, ${ }^{8-12)}$ palhinines, ${ }^{13-15)}$ and seychellene. ${ }^{16-18)}$ These types of compounds with (homo)isotwistane skeleton were attracted by their potential for perfumery, and the difference of scent derived from their chirality could be an important research target. Due to the unique structure of isotwistanes, the total syntheses of biologically active compounds with isotwistane skeletons have been studied by many research groups. ${ }^{19-23)}$ Most of these studies have used the intramolecular DielsAlder reaction to build the fused structure of isotwistane. Based on these previous studies, we planned the synthesis of a chiral isotwistane skeleton by two Diels-Alder reactions: our asymmetric Diels-Alder reaction and a sequential intramo- lecular Diels-Alder reaction.

Dienophiles 2a-d with an olefin in the side chain (R) were prepared. We expected that Lewis acidic activation of the dienophile would occur site-specifically only at the acyloxazolidinone moiety, and the Diels-Alder reaction would take place at the adjacent olefin. With the application of our ytterbium catalyst, ${ }^{3)}$ the asymmetric Diels-Alder reaction proceeded chemoselectively. Moreover, no diastereoisomer of 3 was observed (Chart 3). After conversion to cyclic enone 4, the enantioselectivity was determined by chiral HPLC.

The key intermediate 7 was synthesized with the use of tert-butyldimethylsilyl (TBS) triflate and triethylamine. Dienes 7c and $\mathbf{d}$ were rather unstable on silica gel, and thus were used for the next reaction after only rough purification. An intramolecular Diels-Alder reaction was performed between the resulting diene moiety and each olefin in the side chain (Chart 4).

Thermal activation of 7 successfully promoted the intramolecular Diels-Alder reaction to give the isotwistane $(\mathbf{8}, n=1)$ or homoisotwistane $(\mathbf{8}, n=2)$ skeleton in moderate yields. For the reaction using $\mathbf{7 c}$ and $\mathbf{d}$, the addition of dibutylhydroxytoluene (BHT) (10 mol \%) was effective for improving the yield of the product. Partial desilylation was observed in every reaction, and therefore the crude mixture of $\mathbf{8}$ was directly treated under acidic conditions to give chiral isotwistane and its analogues $\mathbf{1 1 .}$

Intermolecular Hetero-Diels-Alder Reaction, and the Synthesis of Aminocyclitols Having successfully obtained the tricyclic carbon frameworks through the intramolecular Diels-Alder reaction, we next extended the application of 7 to the intermolecular Diels-Alder reaction. While we tried several dienophiles, nitrosobenzene ${ }^{24,25)}$ was quite reactive in the Diels-Alder reaction with 7e. The reaction was completed in hexane at $40^{\circ} \mathrm{C}$, and afforded the bicyclic compound $\mathbf{1 2}$ in $90 \%$ yield (major-minor $=79: 11$, Chart 5 ). The relative stereochemistry of the major product was confirmed by X-ray crystallographic analysis. ${ }^{26)}$

To evaluate the steric effect of the oxazolidinone group on the diastereoselectivity, the acyl-oxazolidinone unit of $7 \mathbf{e}$ 


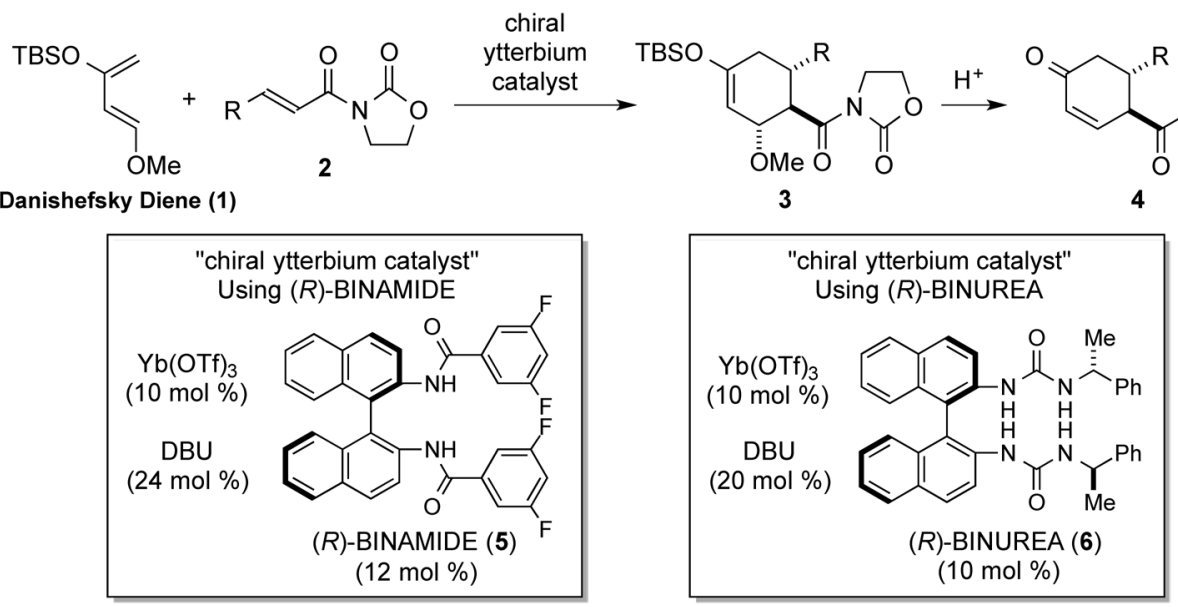

Chart 1. Enantioselective Diels-Alder Reaction of Danishefsky Diene (1)

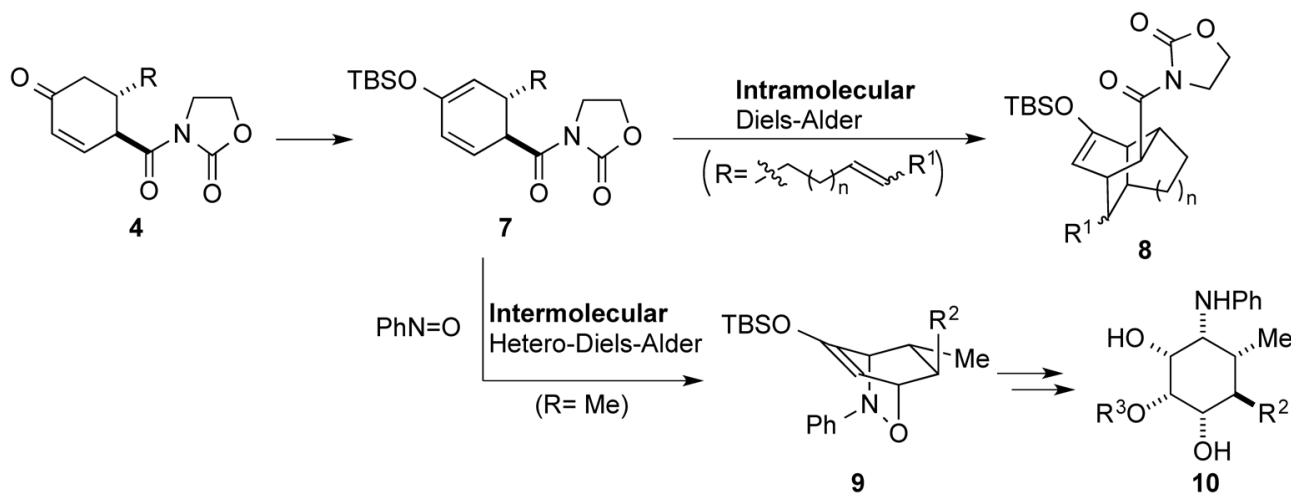

Chart 2. Synthetic Applications of Cyclohexadiene 7 via the Diels-Alder Reaction

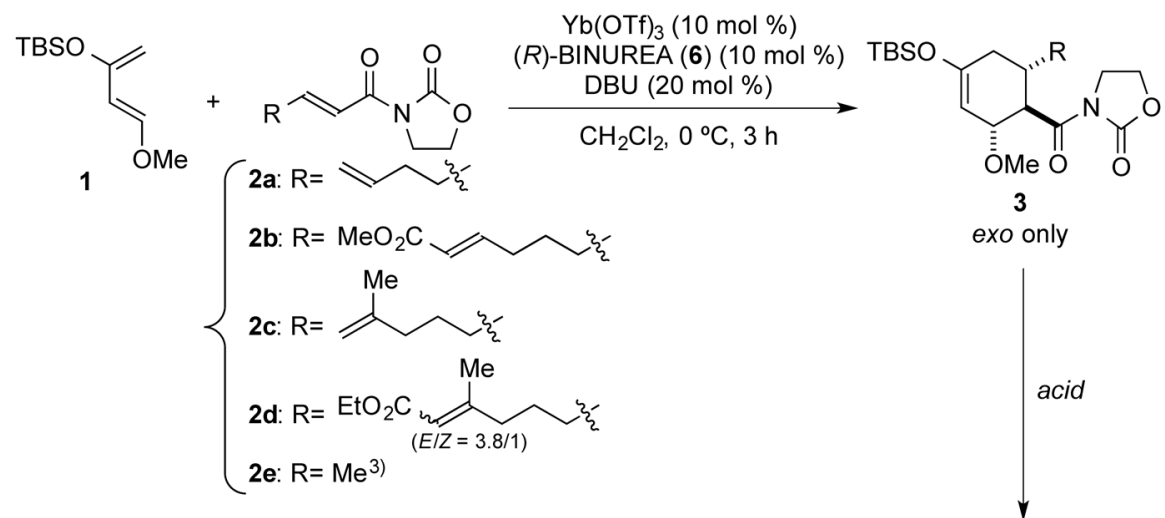
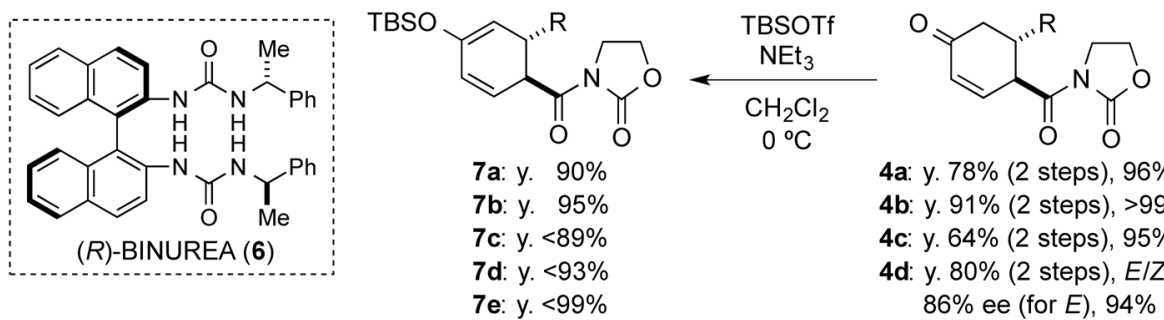

4a: y. $78 \%$ (2 steps), $96 \%$ ee

4b: y. $91 \%$ (2 steps), $>99.5 \%$ ee

4c: y. $64 \%$ (2 steps), $95 \%$ ee

4d: $y .80 \%$ (2 steps), $E / Z=3.5 / 1$

$86 \%$ ee (for $E$ ), $94 \%$ ee (for $Z$ )

4e: y. $99 \%$ (2 steps), $96 \%$ ee

Chart 3. Catalytic and Asymmetric Diels-Alder Reaction Using Dienophile 2, and Conversion to Siloxy-Substituted Cyclohexadiene 7

was converted to a primary alcohol as shown in Chart 6. The intermolecular hetero-Diels-Alder reaction of $\mathbf{1 3}$ with nitrosobenzene proceeded smoothly at room temperature to give cycloadducts 14 in $82 \%$ yield (major-minor=76:9) with opposite $\pi$-face selectivity.

The relative stereochemistry of each diastereomer of $\mathbf{1 4}$ was 


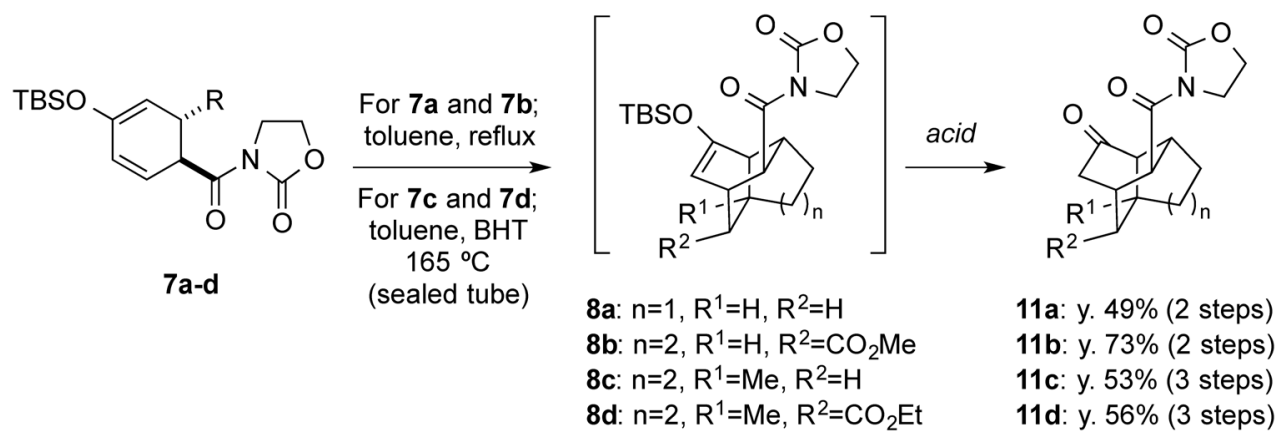

Chart 4. Intramolecular Diels-Alder Reaction<smiles>C[C@H]1C=C(OC(C)(C)C)C=C[C@H]1C(=O)N1CCO[C@@H]1C</smiles>

$7 e$<smiles>O=Nc1ccccc1</smiles>

(1.2 equiv.)

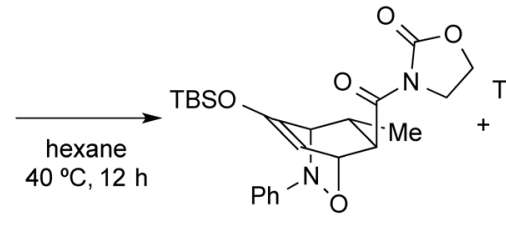

12 major y. $79 \%$

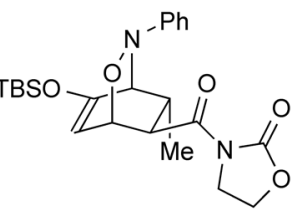

12 minor y. $11 \%$

Chart 5. Intermolecular Hetero-Diels-Alder Reaction with Nitrosobenzene

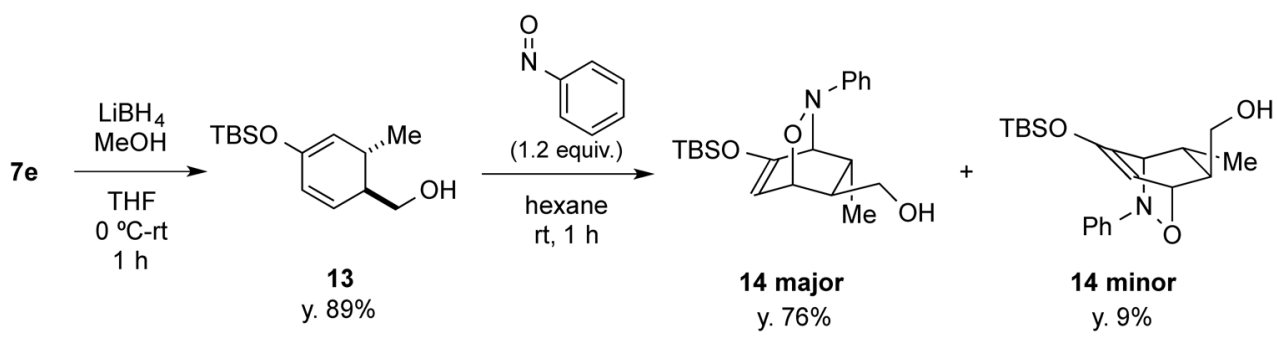

Chart 6. Intermolecular Diels-Alder Reaction of $\mathbf{1 3}$ with Nitrosobenzene
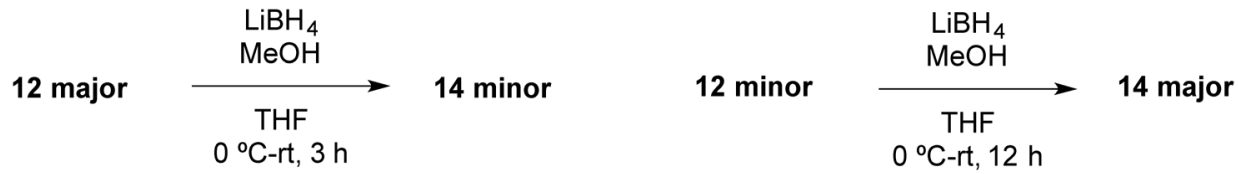

Chart 7. Determination of the Relative Stereochemistry of $\mathbf{1 4}$

determined as follows: reduction of the acyl-oxazolidinone moiety of $\mathbf{1 2}$ major with $\mathrm{LiBH}_{4}$ afforded $\mathbf{1 4}$ minor (Chart 7), both of which had comparable spectral data. In contrast, the reduction of $\mathbf{1 2}$ minor gave $\mathbf{1 4}$ major. Acyl-oxazolidinone and primary alcohol affected the facial selectivity of the diene compound in the hetero-Diels-Alder reaction. Thus, we realized the stereoselective access to both diastereoisomers of hetero-bicycle 12 and 14. Furthermore, no regioisomer was observed.

The $\mathrm{N}-\mathrm{O}$ bond of $\mathbf{1 2}$ major was then successfully cleaved by hydrogenolysis without loss of the silyl enol ether moiety, and sequential Rubottom oxidation afforded pentasubstituted cyclohexanone 16 (Chart 8). The stereochemistry of the newly bound oxygen functionality was unambiguously confirmed by X-ray crystallographic analysis of compound 1 17. $^{27}$

Chemo- and stereoselective reduction of the carbonyl of $\mathbf{1 6}$ afforded hexasubstituted cyclohexane derivative $\mathbf{1 8}$ in $86 \%$ yield with good diastereoselectivity (Chart 9). The relative

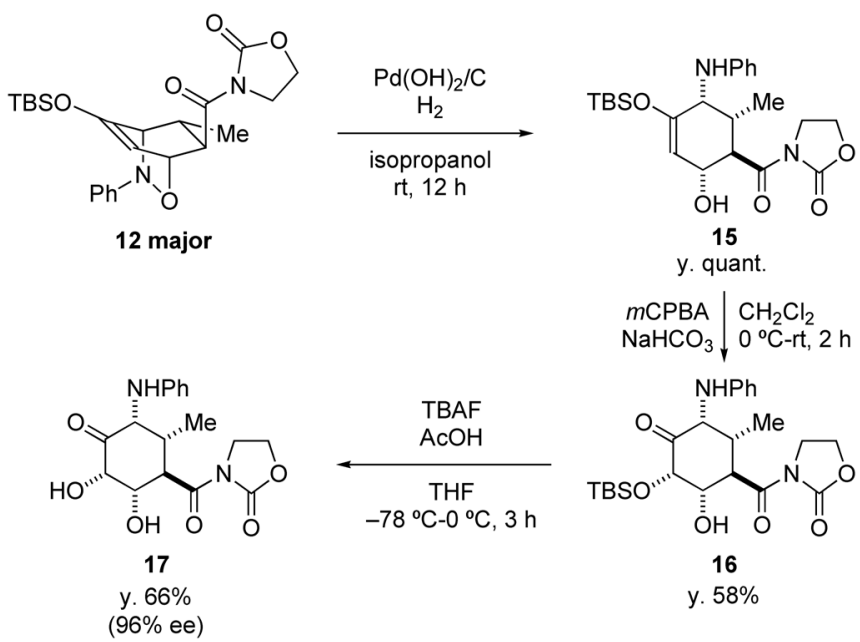

Chart 8. Transformation to Pentasubstituted Cyclohexanone 


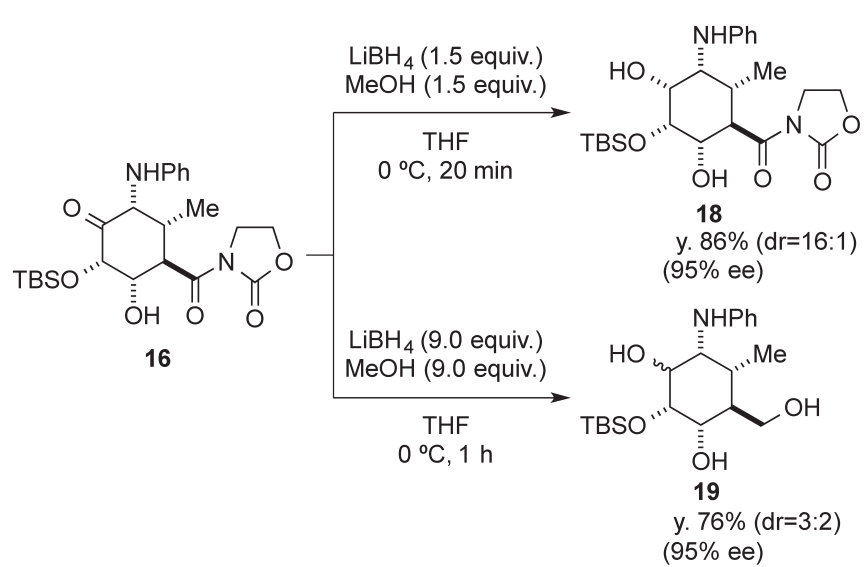

Chart 9. Synthesis of Aminocyclitols Starting from 4e with 95\% Enantiomeric Excess (ee)

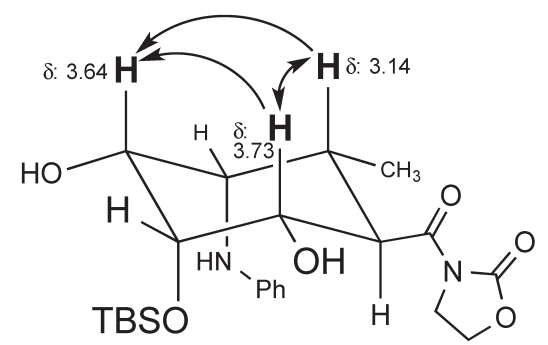

18 major

Fig. 1. Key $n$ Oe Correlations of $\mathbf{1 8}$ Major

configuration of $\mathbf{1 8}$ major was identified by a $n$ Oe experiment (Fig. 1). Attempted conversion to triol 19 from isolated 18 with 1.5 equiv. of lithium borohydride resulted in messy reaction mixture. Alternatively, triol 19 was obtained with the use of an excess amount of lithium borohydride to 16, although the diastereoselectivity of the reduction of carbonyl was decreased to $3: 2$. These hexasubstituted chiral cyclohexanes 18 and 19 could be used for the synthesis of chiral aminocyclitols and their derivatives. ${ }^{28)}$ In addition, no racemization was observed throughout the whole process in Charts 8 and 9.

\section{Conclusion}

We have achieved two synthetic applications of our asymmetric Diels-Alder reaction using chiral cyclohexadiene 7 as a common intermediate. The intramolecular Diels-Alder reaction was used to give the isotwistane and homoisotwistane skeletons. The conversion to aminocyclitols was also accomplished via the intermolecular hetero-Diels-Alder reaction of 7. These results extend the versatility of our ytterbium catalysis.

\section{Experimental}

General Information NMR spectra were recorded at 400 or $600 \mathrm{MHz}$ for ${ }^{1} \mathrm{H}-\mathrm{NMR}$, and at 100 or $150 \mathrm{MHz}$ for ${ }^{13} \mathrm{C}-\mathrm{NMR}$. Chemical shifts for proton are reported in parts per million downfield from tetramethylsilane, and are referenced to residual protium in the NMR solvent $\left(\mathrm{CDCl}_{3} \delta: 7.26 \mathrm{ppm}\right)$. For ${ }^{13} \mathrm{C}-\mathrm{NMR}$, chemical shifts were reported in the scale relative to the $\mathrm{NMR}$ solvent $\left(\mathrm{CDCl}_{3} \delta: 77.0 \mathrm{ppm}\right)$ as an internal reference. Infrared spectra were recorded on an attenuated total reflectance (ATR). Optical rotations were measured at $589 \mathrm{~nm}$. Mass spectra were recorded using electrospray ionization (ESI) mode with TOF analyzer. The enantiomeric excess (ee) was determined by HPLC analysis measured at $254 \mathrm{~nm}$. $\mathrm{X}$-Ray crystallographic data were collected at $-180^{\circ} \mathrm{C}$ using filtered $\mathrm{Cu}-\mathrm{K} \alpha$ radiation. Reactions were carried out in dry solvents under an argon atmosphere, unless otherwise noted. Dry $\mathrm{CH}_{2} \mathrm{Cl}_{2}$ for catalyst was purchased from Kanto Chemical Co., Inc. Ytterbium(III) trifluoromethanesulfonate $\left(\mathrm{Yb}(\mathrm{OTf})_{3}\right)$ was purchased from Aldrich. Other solvents and reagents were purified by usual methods. Flash column chromatography was performed on silica gel, $60 \mu \mathrm{m}$ particle, unless otherwise noted.

Dienophiles $\mathbf{2 a}-\mathbf{d}$ were synthesized by following known procedures. Spectral data of synthetic intermediates were also identified with the data in references.

(E)-3-(Hepta-2,6-dienoyl)oxazolidin-2-one (2a) ${ }^{29-31)}$ ${ }^{1} \mathrm{H}-\mathrm{NMR}\left(400 \mathrm{MHz}, \mathrm{CDCl}_{3}\right) \delta: 2.25(2 \mathrm{H}, \mathrm{dt}, J=6.4,6.4 \mathrm{~Hz})$, $2.39(2 \mathrm{H}, \mathrm{dt}, J=6.8,6.8 \mathrm{~Hz}), 4.07(2 \mathrm{H}, \mathrm{t}, J=8.4 \mathrm{~Hz}), 4.42(2 \mathrm{H}$, $\mathrm{d}, J=8.4 \mathrm{~Hz}), 5.01(1 \mathrm{H}, \mathrm{ddt}, J=2.0,2.0,10.0 \mathrm{~Hz}), 5.04(1 \mathrm{H}$, $\mathrm{ddt}, J=2.0,2.0,16.8 \mathrm{~Hz}), 5.81(1 \mathrm{H}, \mathrm{ddt}, J=6.4,10.0,16.4 \mathrm{~Hz})$, $7.16(1 \mathrm{H}, \mathrm{dt}, J=6.4,15.2 \mathrm{~Hz}), 7.26(1 \mathrm{H}, \mathrm{dt}, J=1.2,15.6 \mathrm{~Hz})$; ${ }^{13} \mathrm{C}-\mathrm{NMR}\left(100 \mathrm{MHz}, \mathrm{CDCl}_{3}\right) \delta: 31.9,32.0,42.7,62.0,115.6$, $120.3,137.0,150.6,153.5,165.2$; IR (ATR): $v$ 2924, 1769, 1681, $1633 \mathrm{~cm}^{-1}$; high resolution (HR)-MS (ESI) $\mathrm{m} / \mathrm{z} 477.2199$ $[2 \mathrm{M}+2 \mathrm{MeOH}+\mathrm{Na}]^{+}$(Calcd for $\mathrm{C}_{22} \mathrm{H}_{34} \mathrm{~N}_{2} \mathrm{O}_{8} \mathrm{Na}$ : 477.2213).

Methyl (2E,7E)-9-Oxo-9-(2-oxooxazolidin-3-yl)nona-2,7dienoate (2b) ${ }^{31-33)} \quad{ }^{1} \mathrm{H}-\mathrm{NMR}\left(400 \mathrm{MHz}, \mathrm{CDCl}_{3}\right) \delta$ : $1.65(2 \mathrm{H}$, tt, $J=8.0,8.0 \mathrm{~Hz}), 2.25(2 \mathrm{H}, \mathrm{dt}, J=7.2,7.2 \mathrm{~Hz}), 2.32(2 \mathrm{H}, \mathrm{dt}$, $J=7.6,7.6 \mathrm{~Hz}), 3.73(3 \mathrm{H}, \mathrm{s}), 4.09(2 \mathrm{H}, \mathrm{t}, J=7.6 \mathrm{~Hz}), 4.43(2 \mathrm{H}$, $\mathrm{t}, J=7.2 \mathrm{~Hz}), 5.84(1 \mathrm{H}, \mathrm{d}, J=15.6 \mathrm{~Hz}), 6.94(1 \mathrm{H}, \mathrm{dt}, J=6.8$, $15.6 \mathrm{~Hz}), 7.13(1 \mathrm{H}, \mathrm{dt}, J=6.8,15.6 \mathrm{~Hz}), 7.25(1 \mathrm{H}, \mathrm{d}, J=15.6 \mathrm{~Hz})$; ${ }^{13} \mathrm{C}-\mathrm{NMR}\left(100 \mathrm{MHz}, \mathrm{CDCl}_{3}\right) \delta: 26.4,31.5,31.9,42.7,51.4$, $62.0,120.6,121.6,148.3,150.2,153.5,165.1,166.9$; IR (ATR): $v$ 2926, 1770, 1717, 1681, $1634 \mathrm{~cm}^{-1}$; HR-MS (ESI) $\mathrm{m} / z$ $400.0160[\mathrm{M}+\mathrm{Cs}]^{+}$(Calcd for $\mathrm{C}_{13} \mathrm{H}_{17} \mathrm{NO}_{5} \mathrm{Cs}: 400.0161$ ).

(E)-3-(7-Methylocta-2,7-dienoyl)oxazolidin-2-one (2c) ${ }^{34-36)}$ ${ }^{1} \mathrm{H}-\mathrm{NMR}\left(600 \mathrm{MHz}, \mathrm{CDCl}_{3}\right) \delta: 1.64(2 \mathrm{H}, \mathrm{tt}, J=7.2,7.2 \mathrm{~Hz})$, $1.71(3 \mathrm{H}, \mathrm{s}), 2.05(2 \mathrm{H}, \mathrm{t}, J=7.8 \mathrm{~Hz}), 2.28(2 \mathrm{H}, \mathrm{dt}, J=7.2$, $7.2 \mathrm{~Hz}), 4.07(2 \mathrm{H}, \mathrm{t}, J=7.8 \mathrm{~Hz}), 4.43(2 \mathrm{H}, \mathrm{t}, J=8.4 \mathrm{~Hz}), 4.69$ $(1 \mathrm{H}, \mathrm{s}), 4.73(1 \mathrm{H}, \mathrm{s}), 7.18(1 \mathrm{H}, \mathrm{dt}, J=7.2,15.0 \mathrm{~Hz}), 7.25(1 \mathrm{H}$, d, $J=15.0 \mathrm{~Hz}) ;{ }^{13} \mathrm{C}-\mathrm{NMR}\left(100 \mathrm{MHz}, \mathrm{CDCl}_{3}\right) \delta: 22.2,25.9$, 32.1, 37.1, 42.7, 62.0, 110.4, 120.2, 145.0, 151.4, 153.5, 165.3; IR (ATR): $v$ 2932, 1770, 1680, $1633 \mathrm{~cm}^{-1}$; HR-MS (ESI) $\mathrm{m} / \mathrm{z}$ $246.1113[\mathrm{M}+\mathrm{Na}]^{+}$(Calcd for $\mathrm{C}_{12} \mathrm{H}_{17} \mathrm{NO}_{3} \mathrm{Na}$ : 246.1106).

Ethyl (7E)-3-Methyl-9-oxo-9-(2-oxooxazolidin-3-yl)nona2,7-dienoate (2d) (for Major $\boldsymbol{E}$-Isomer) ${ }^{34,36,37)}{ }^{1} \mathrm{H}-\mathrm{NMR}$ $\left(400 \mathrm{MHz}, \mathrm{CDCl}_{3}\right) \delta: 1.28(3 \mathrm{H}, \mathrm{t}, J=7.6 \mathrm{~Hz}), 1.69(2 \mathrm{H}, \mathrm{tt}$, $J=7.6,7.6 \mathrm{~Hz}), 2.15(3 \mathrm{H}, \mathrm{d}, J=1.2 \mathrm{~Hz}), 2.18(2 \mathrm{H}, \mathrm{t}, J=7.6 \mathrm{~Hz})$, $2.29(2 \mathrm{H}, \mathrm{dt}, J=8.0,8.0 \mathrm{~Hz}), 4.08(2 \mathrm{H}, \mathrm{t}, J=8.0 \mathrm{~Hz}), 4.15$ $(2 \mathrm{H}, \mathrm{q}, J=7.2 \mathrm{~Hz}), 4.43(2 \mathrm{H}, \mathrm{t}, J=8.0 \mathrm{~Hz}), 5.67(1 \mathrm{H}, \mathrm{s}), 7.14$ $(1 \mathrm{H}, \mathrm{dt}, J=8.8,15.4 \mathrm{~Hz}), 7.25(1 \mathrm{H}, \mathrm{d}, J=15.4 \mathrm{~Hz}) ;{ }^{13} \mathrm{C}-\mathrm{NMR}$ $\left(100 \mathrm{MHz}, \mathrm{CDCl}_{3}\right) \delta: 14.2,18.6,25.7,31.9,40.1,42.7,59.5$, $62.0,116.1,120.5,150.4,153.5,158.8,165.1,166.7$; IR (ATR): $v$ 2916, 1772, 1707, 1681, $1631 \mathrm{~cm}^{-1}$; HR-MS (ESI) $\mathrm{m} / z 318.1318$ $[\mathrm{M}+\mathrm{Na}]^{+}$(Calcd for $\mathrm{C}_{15} \mathrm{H}_{21} \mathrm{NO}_{5} \mathrm{Na}$ : 318.1317).

3-((1R,6S)-6-(But-3-en-1-yl)-4-oxocyclohex-2-ene-1-carbonyl)oxazolidin-2-one (4a) $\mathrm{Yb}(\mathrm{OTf})_{3} \quad(37.2 \mathrm{mg}, 60.0 \mu \mathrm{mol})$ and $(R)$-BINUREA $(6)^{3)}(34.8 \mathrm{mg}, 60.0 \mu \mathrm{mol})$ taken in a test tube with a stirring bar were heated at $120^{\circ} \mathrm{C}$ under reduced 
pressure $(<0.1 \mathrm{mmHg})$ for $30 \mathrm{~min}$. After being allowed to cool to room temperature, the test tube was charged with dry argon. Dichloromethane $\left(\mathrm{CH}_{2} \mathrm{Cl}_{2}\right)(2.0 \mathrm{~mL})$ and 1,8-diazabicyclo[5.4.0]undec-7-ene (DBU) $(18.0 \mu \mathrm{L}, 120.0 \mu \mathrm{mol})$ were added successively, and the resulting solution was stirred for $2 \mathrm{~h}$ at room temperature. The reaction vessel was cooled to $0^{\circ} \mathrm{C}$ and a solution of dienophile $2 \mathrm{a}(117.1 \mathrm{mg}, 0.60 \mathrm{mmol})$ in $\mathrm{CH}_{2} \mathrm{Cl}_{2}(1.0 \mathrm{~mL})$ was added, followed by the addition of Danishefsky diene (1) $(300 \mu \mathrm{L}, 1.2 \mathrm{mmol})$. The mixture was stirred at the same temperature for $3 \mathrm{~h}$, and water $(5.0 \mathrm{~mL})$ was then added. Insoluble materials were filtered through a pad of Celite ${ }^{\circledR}$. The water layer was extracted three times with $\mathrm{CH}_{2} \mathrm{Cl}_{2}$, and the combined organic layers were washed with brine and dried over $\mathrm{Na}_{2} \mathrm{SO}_{4}$. After the volatile materials were removed under reduced pressure, the diastereoselectivity (a single diastereomer) was checked by ${ }^{1} \mathrm{H}-\mathrm{NMR}$. The crude product could be purified by column chromatography $\left(\mathrm{SiO}_{2}\right.$, hexane-AcOEt $=5: 1$ ) to give $\mathbf{3 a}$.

The resulting crude mixture of $\mathbf{3 a}$ was dissolved in $\mathrm{CH}_{2} \mathrm{Cl}_{2}$ $(3.0 \mathrm{~mL})$, and trifluoroacetic acid (TFA) $(0.3 \mathrm{~mL})$ was added at $0^{\circ} \mathrm{C}$. After being stirred for $10 \mathrm{~min}$ at room temperature, the reaction was quenched by the addition of aqueous saturated $\mathrm{NaHCO}_{3}$. The mixture was extracted three times with $\mathrm{CH}_{2} \mathrm{Cl}_{2}$, and the combined organic layers were washed with brine, and dried over $\mathrm{Na}_{2} \mathrm{SO}_{4}$. After the volatile materials were removed under reduced pressure, the resulting residue was purified by column chromatography $\left(\mathrm{SiO}_{2}\right.$, hexane-AcOEt=1:1) to give 4a $(123.6 \mathrm{mg}, 78 \%)$. The enantiomeric excess was determined by chiral HPLC analysis. ${ }^{1} \mathrm{H}-\mathrm{NMR}\left(400 \mathrm{MHz}, \mathrm{CDCl}_{3}\right) \quad \delta$ : $1.43-1.62(2 \mathrm{H}, \mathrm{m}), 2.03$ (1H, dddd, $J=7.6,7.6,7.6,14.4 \mathrm{~Hz})$, $2.12-2.21(1 \mathrm{H}, \mathrm{m}), 2.26(1 \mathrm{H}, \mathrm{dd}, J=10.0,16.4 \mathrm{~Hz}), 2.53-2.64$ $(1 \mathrm{H}, \mathrm{m}), 2.79(1 \mathrm{H}, \mathrm{dd}, J=4.4,16.4 \mathrm{~Hz}), 4.10(2 \mathrm{H}, \mathrm{dddt}, J=3.6$, $3.6,8.4,19.6 \mathrm{~Hz}), 4.49(2 \mathrm{H}, \mathrm{t}, J=8.4 \mathrm{~Hz}), 4,63(1 \mathrm{H}, \mathrm{dt}, J=3.2$, $7.6 \mathrm{~Hz}), 4.98(1 \mathrm{H}, \mathrm{dd}, J=1.6,10.0 \mathrm{~Hz}), 5.03(1 \mathrm{H}$, dddd, $J=1.2$, $1.2,1.2,16.8 \mathrm{~Hz}), 5.75(1 \mathrm{H}, \mathrm{dddd}, J=6.8,6.8,10.8,17.2 \mathrm{~Hz})$, $6.12(1 \mathrm{H}, \mathrm{dd}, J=2.8,10.0 \mathrm{~Hz}), 6.73(1 \mathrm{H}, \mathrm{dd}, J=3.2,10.0 \mathrm{~Hz})$; ${ }^{13} \mathrm{C}-\mathrm{NMR}\left(100 \mathrm{MHz}, \mathrm{CDCl}_{3}\right) \delta: 30.5,32.8,36.4,40.9,42.8$, 46.4, 62.1, 115.3, 130.7, 137.5, 144.5, 153.2, 171.7, 198.1; IR (ATR): $v$ 2924, 1769, $1675 \mathrm{~cm}^{-1}$; HR-MS (ESI) $\mathrm{m} / \mathrm{z} 286.1056$ $[\mathrm{M}+\mathrm{Na}]^{+}\left(\mathrm{Calcd}\right.$ for $\left.\mathrm{C}_{14} \mathrm{H}_{17} \mathrm{NO}_{4} \mathrm{Na}: 286.1055\right) ;[\alpha]_{\mathrm{D}}^{23}+167.4$ $\left(c=1.02, \mathrm{CHCl}_{3}\right)$; HPLC conditions Daicel CHIRALPAK AS-H, e: Hex-IPA $=60: 40, f=0.8 \mathrm{~mL} / \mathrm{min}, \mathrm{t}: 18.3$ (major) and 25.0 (minor) $\min$.

Methyl (E)-6-((1S,2R)-5-Oxo-2-(2-oxooxazolidine-3carbonyl)cyclohex-3-en-1-yl)hex-2-enoate (4b) $\mathrm{Yb}(\mathrm{OTf})_{3}$ $(37.2 \mathrm{mg}, \quad 60.0 \mu \mathrm{mol})$ and (R)-BINUREA $(6)^{3)} \quad(34.8 \mathrm{mg}$, $60.0 \mu \mathrm{mol})$ taken in a test tube with a stirring bar were heated at $120^{\circ} \mathrm{C}$ under reduced pressure $(<0.1 \mathrm{mmHg})$ for $30 \mathrm{~min}$. After being allowed to cool to room temperature, the test tube was charged with dry argon. Dichloromethane $\left(\mathrm{CH}_{2} \mathrm{Cl}_{2}\right)$ $(2.0 \mathrm{~mL})$ and DBU $(18.0 \mu \mathrm{L}, 120.0 \mu \mathrm{mol})$ were added successively, and the resulting solution was stirred for $2 \mathrm{~h}$ at room temperature. The reaction vessel was cooled to $0^{\circ} \mathrm{C}$ and a solution of dienophile $\mathbf{2 b}(160.4 \mathrm{mg}, 0.60 \mathrm{mmol})$ in $\mathrm{CH}_{2} \mathrm{Cl}_{2}$ $(1.0 \mathrm{~mL})$ was added, followed by the addition of Danishefsky diene (1) $(163 \mu \mathrm{L}, 0.66 \mathrm{mmol})$. The mixture was stirred at the same temperature for $3 \mathrm{~h}$, and water $(5.0 \mathrm{~mL})$ was then added. Insoluble materials were filtered through a pad of Celite ${ }^{\circledR}$. The water layer was extracted three times with $\mathrm{CH}_{2} \mathrm{Cl}_{2}$, and the combined organic layers were washed with brine and dried over $\mathrm{Na}_{2} \mathrm{SO}_{4}$. After the volatile materials were removed under reduced pressure, the diastereoselectivity (a single diastereomer) was checked by ${ }^{1} \mathrm{H}-\mathrm{NMR}$. The crude product could be purified by column chromatography $\left(\mathrm{SiO}_{2}\right.$, hexane$\mathrm{AcOEt}=5: 1)$ to give $\mathbf{3 b}$.

The resulting crude mixture $\mathbf{3 b}$ was dissolved in $\mathrm{CH}_{2} \mathrm{Cl}_{2}$ $(3.0 \mathrm{~mL})$, and $\mathrm{BF}_{3} \cdot \mathrm{OEt}_{2}(188 \mu \mathrm{L}, 1.5 \mathrm{mmol})$ was added at $-78^{\circ} \mathrm{C}$. After being stirred for $10 \mathrm{~min}$ at the same temperature, the reaction was quenched by the addition of aqueous saturated $\mathrm{NaHCO}_{3}$. The mixture was extracted three times with $\mathrm{CH}_{2} \mathrm{Cl}_{2}$, and the combined organic layers were washed with brine, and dried over $\mathrm{Na}_{2} \mathrm{SO}_{4}$. After the volatile materials were removed under reduced pressure, the resulting residue was purified by column chromatography $\left(\mathrm{SiO}_{2}\right.$, hexaneAcOEt $=1: 1)$ to give $4 \mathbf{b}(183.4 \mathrm{mg}, 91 \%)$. The enantiomeric excess was determined by HPLC analysis. ${ }^{1} \mathrm{H}-\mathrm{NMR}(400 \mathrm{MHz}$, $\left.\mathrm{CDCl}_{3}\right) \delta: 1.38-1.54(4 \mathrm{H}, \mathrm{m}), 2.16-1.25(2 \mathrm{H}, \mathrm{m}), 2.25(1 \mathrm{H}$, $\mathrm{dd}, J=10.4,16.0 \mathrm{~Hz}), 2.53-2.62(1 \mathrm{H}, \mathrm{m}), 2.76(1 \mathrm{H}, \mathrm{dd}, J=4.4$, $16.4 \mathrm{~Hz}), 3.73(2 \mathrm{H}, \mathrm{s}), 4.10(2 \mathrm{H}, \mathrm{dddt}, J=4.4,4.4,8.0,16.0 \mathrm{~Hz})$, $4.50(2 \mathrm{H}, \mathrm{dt}, J=2.0,8.0 \mathrm{~Hz}), 4.62(1 \mathrm{H}, \mathrm{dt}, J=3.6,7.2 \mathrm{~Hz}), 5.81$ $(1 \mathrm{H}, \mathrm{ddd}, J=2.0,2.0,16.4 \mathrm{~Hz}), 6.13(1 \mathrm{H}, \mathrm{dd}, J=2.4,10.0 \mathrm{~Hz})$, $6.72(1 \mathrm{H}, \mathrm{dd}, J=3.2,10.0 \mathrm{~Hz}), 6.90(1 \mathrm{H}, \mathrm{ddd}, J=7.6,7.6$, $15.6 \mathrm{~Hz}) ;{ }^{13} \mathrm{C}-\mathrm{NMR}\left(100 \mathrm{MHz}, \mathrm{CDCl}_{3}\right) \delta: 24.8,31.8,33.2,36.6$, $41.0,42.8,46.3,51.4,62.2,121.5,130.7,144.5,148.5,153.3$, 167.0, 171.6, 198.0; IR (ATR): $v$ 2926, 1771, $1677 \mathrm{~cm}^{-1}$; HR-MS (ESI) $m / z \quad 358.1272 \quad[\mathrm{M}+\mathrm{Na}]^{+}$(Calcd for $\mathrm{C}_{17} \mathrm{H}_{21} \mathrm{NO}_{6} \mathrm{Na}$ : 358.1267); $[\alpha]_{\mathrm{D}}^{23}+107.2\left(c=1.02, \mathrm{CHCl}_{3}\right)$; HPLC conditions Daicel CHIRALCEL OJ-H, e: Hex-IPA $=55: 45, f=0.8 \mathrm{~mL} /$ min, t: 34.7 (minor) and 37.9 (major) $\mathrm{min}$.

3-((1R,6S)-6-(4-Methylpent-4-en-1-yl)-4-oxocyclohex2-ene-1-carbonyl)oxazolidin-2-one (4c) $\mathrm{Yb}(\mathrm{OTf})_{3}$ (47.1 mg, $76.0 \mu \mathrm{mol})$ and $(R)$-BINUREA $(6)^{3)}(44.1 \mathrm{mg}, 76.0 \mu \mathrm{mol})$ taken in a test tube with a stirring bar were heated at $120^{\circ} \mathrm{C}$ under reduced pressure $(<0.1 \mathrm{mmHg})$ for $30 \mathrm{~min}$. After being allowed to cool to room temperature, the test tube was charged with dry argon. Dichloromethane $\left(\mathrm{CH}_{2} \mathrm{Cl}_{2}\right)(2.5 \mathrm{~mL})$ and DBU $(22.8 \mu \mathrm{L}, 132.0 \mu \mathrm{mol})$ were added successively, and the resulting solution was stirred for $2 \mathrm{~h}$ at room temperature. The reaction vessel was cooled to $0^{\circ} \mathrm{C}$ and a solution of dienophile 2c $(170 \mathrm{mg}, 0.76 \mathrm{mmol})$ in $\mathrm{CH}_{2} \mathrm{Cl}_{2}(1.2 \mathrm{~mL})$ was added, followed by the addition of Danishefsky diene (1) $(369 \mu \mathrm{L}$, $1.52 \mathrm{mmol}$ ). The mixture was stirred at the same temperature for $3 \mathrm{~h}$, and water $(5.0 \mathrm{~mL})$ was then added. Insoluble materials were filtered through a pad of Celite ${ }^{\circledR}$. The water layer was extracted three times with $\mathrm{CH}_{2} \mathrm{Cl}_{2}$, and the combined organic layers were washed with brine and dried over $\mathrm{Na}_{2} \mathrm{SO}_{4}$. After the volatile materials were removed under reduced pressure, the diastereoselectivity (a single diastereomer) was checked by ${ }^{1} \mathrm{H}-\mathrm{NMR}$. The crude product could be purified by column chromatography $\left(\mathrm{SiO}_{2}\right.$, hexane-AcOEt $\left.=5: 1\right)$ to give $3 \mathbf{c}$.

The resulting crude mixture of $\mathbf{3 c}$ was dissolved in $\mathrm{CH}_{2} \mathrm{Cl}_{2}$ $(3.0 \mathrm{~mL})$, and TFA $(0.3 \mathrm{~mL})$ was added at $0^{\circ} \mathrm{C}$. After being stirred for $10 \mathrm{~min}$ at room temperature, the reaction was quenched by the addition of aqueous saturated $\mathrm{NaHCO}_{3}$. The mixture was extracted three times with $\mathrm{CH}_{2} \mathrm{Cl}_{2}$, and the combined organic layers were washed with brine, and dried over $\mathrm{Na}_{2} \mathrm{SO}_{4}$. After the volatile materials were removed under reduced pressure, the resulting residue was purified by column chromatography $\left(\mathrm{SiO}_{2}\right.$, hexane-AcOEt=1:1) to give $\mathbf{4 c}$ (142.8 mg, 64\%). The enantiomeric excess was determined by chiral HPLC analysis. ${ }^{1} \mathrm{H}-\mathrm{NMR}\left(400 \mathrm{MHz}, \mathrm{CDCl}_{3}\right) \delta: 1.22$ $(1 \mathrm{H}, \mathrm{d}, J=6.0 \mathrm{~Hz}), 1.35-1.49(3 \mathrm{H}, \mathrm{m}), 1.68(3 \mathrm{H}, \mathrm{s}), 1.94-2.01$ 
$(2 \mathrm{H}, \mathrm{m}), 2.26(1 \mathrm{H}, \mathrm{dd}, J=10.0,16.0 \mathrm{~Hz}), 2.53-2.62(1 \mathrm{H}, \mathrm{m})$, $2.78(1 \mathrm{H}, \mathrm{dd}, J=4.8,16.4 \mathrm{~Hz}), 4.10(2 \mathrm{H}, \mathrm{t}, J=7.6 \mathrm{~Hz}), 4.50$ $(2 \mathrm{H}, \mathrm{t}, J=8.4 \mathrm{~Hz}), 4.62(1 \mathrm{H}, \mathrm{ddd}, J=3.2,3.2,7.2 \mathrm{~Hz}), 4.64(1 \mathrm{H}$, s), $4.70(1 \mathrm{H}, \mathrm{s}), 6.12(1 \mathrm{H}, \mathrm{dd}, J=2.8,10.0 \mathrm{~Hz}), 6.73(1 \mathrm{H}, \mathrm{dd}$, $J=3.2,10.0 \mathrm{~Hz}) ;{ }^{13} \mathrm{C}-\mathrm{NMR}\left(100 \mathrm{MHz}, \mathrm{CDCl}_{3}\right) \delta: 22.3,24.3$, $33.3,36.9,37.4,41.2,42.8,46.5,62.1,110.2,130.7,144.7$, 145.3, 153.2, 171.8, 198.3; IR (ATR): v 2931, 1771, $1676 \mathrm{~cm}^{-1}$; HR-MS (ESI) $m / z$ 314.1365 [M+Na $]^{+}$(Calcd for $\mathrm{C}_{16} \mathrm{H}_{21} \mathrm{NO}_{4} \mathrm{Na}$ : 314.1368); $[\alpha]_{\mathrm{D}}^{24}+143.3\left(c=0.99, \mathrm{CHCl}_{3}\right) ; \mathrm{HPLC}$ conditions Daicel CHIRALPAK IA, e: Hex-IPA $=80: 20, f=1.0 \mathrm{~mL} / \mathrm{min}$, t: 37.7 (minor) and 39.9 (major) min.

Ethyl 3-Methyl-6-((1S,2R)-5-oxo-2-(2-oxooxazolidine3-carbonyl)cyclohex-3-en-1-yl)hex-2-enoate (4d Major) $\mathrm{Yb}(\mathrm{OTf})_{3} \quad(51.5 \mathrm{mg}, \quad 83.0 \mu \mathrm{mol})$ and $(R)$-BINUREA $(6)^{3)}$ $(48.1 \mathrm{mg}, 83.0 \mu \mathrm{mol})$ taken in a test tube with a stirring bar were heated at $120^{\circ} \mathrm{C}$ under reduced pressure $(<0.1 \mathrm{mmHg})$ for $30 \mathrm{~min}$. After being allowed to cool to room temperature, the test tube was charged with dry argon. Dichloromethane $\left(\mathrm{CH}_{2} \mathrm{Cl}_{2}\right)(2.8 \mathrm{~mL})$ and DBU $(24.9 \mu \mathrm{L}, 166.0 \mu \mathrm{mol})$ were added successively, and the resulting solution was stirred for $2 \mathrm{~h}$ at room temperature. The reaction vessel was cooled to $0^{\circ} \mathrm{C}$ and a solution of dienophile $2 \mathbf{d}(300.0 \mathrm{mg}, 0.83 \mathrm{mmol})$ in $\mathrm{CH}_{2} \mathrm{Cl}_{2}$ $(1.4 \mathrm{~mL})$ was added, followed by the addition of Danishefsky diene (1) $(415 \mu \mathrm{L}, 1.66 \mathrm{mmol})$. The mixture was stirred at the same temperature for $3 \mathrm{~h}$, and water $(5.0 \mathrm{~mL})$ was then added. Insoluble materials were filtered through a pad of Celite ${ }^{\circledR}$. The water layer was extracted three times with $\mathrm{CH}_{2} \mathrm{Cl}_{2}$, and the combined organic layers were washed with brine and dried over $\mathrm{Na}_{2} \mathrm{SO}_{4}$. After the volatile materials were removed under reduced pressure, the diastereoselectivity (a single diastereomer) was checked by ${ }^{1} \mathrm{H}-\mathrm{NMR}$. The crude product could be purified by column chromatography $\left(\mathrm{SiO}_{2}\right.$, hexane$\mathrm{AcOEt}=5: 1)$ to give $\mathbf{3 d}$.

The resulting crude mixture of $\mathbf{3 d}$ was dissolved in $\mathrm{CH}_{2} \mathrm{Cl}_{2}$ $(3.0 \mathrm{~mL})$, and TFA $(0.3 \mathrm{~mL})$ was added at $0^{\circ} \mathrm{C}$. After being stirred for $10 \mathrm{~min}$ at room temperature, the reaction was quenched by the addition of aqueous saturated $\mathrm{NaHCO}_{3}$. The mixture was extracted three times with $\mathrm{CH}_{2} \mathrm{Cl}_{2}$, and the combined organic layers were washed with brine, and dried over $\mathrm{Na}_{2} \mathrm{SO}_{4}$. After the volatile materials were removed under reduced pressure, the resulting residue was purified by column chromatography $\left(\mathrm{SiO}_{2}\right.$, hexane-AcOEt $\left.=1: 1\right)$ to give $\mathbf{4 d}$ $(241.5 \mathrm{mg}, 80 \%)$. The enantiomeric excess was determined by chiral HPLC analysis. ${ }^{1} \mathrm{H}-\mathrm{NMR}\left(400 \mathrm{MHz}, \mathrm{CDCl}_{3}\right) \delta: 0.88$ $(1 \mathrm{H}, \mathrm{dd}, J=6.8,6.8 \mathrm{~Hz}), 1.24-1.30(4 \mathrm{H}, \mathrm{m}), 1.38-1.47(3 \mathrm{H}, \mathrm{m})$, 2.09-2.14 (4H, m), 2.26 (1H, dd, $J=11.2,16.4 \mathrm{~Hz}), 2.53-2.59$ (1H, m), $2.76(1 \mathrm{H}, \mathrm{dd}, J=4.4,16.4 \mathrm{~Hz}), 4.08-4.14$ (4H, m), 4.50 $(2 \mathrm{H}, \mathrm{t}, J=8.0 \mathrm{~Hz}), 4.61(1 \mathrm{H}, \mathrm{dd}, J=3.2,3.2 \mathrm{~Hz}), 5.63(1 \mathrm{H}, \mathrm{s})$, $6.12(1 \mathrm{H}, \mathrm{dd}, J=1.2,10.0 \mathrm{~Hz}), 6.72(1 \mathrm{H}, \mathrm{dd}, J=3.2,10.0 \mathrm{~Hz})$; ${ }^{13} \mathrm{C}-\mathrm{NMR}\left(100 \mathrm{MHz}, \mathrm{CDCl}_{3}\right) \delta: 14.3,18.5,24.1,33.2,36.8$, $40.3,41.1,42.8,46.4,59.5,62.2,116.0,130.7,144.5,153.2$, 158.9, 166.7, 171.7, 198.0; IR (ATR): v 2935, 1772, 1677, $1646 \mathrm{~cm}^{-1}$; HR-MS (ESI) $\mathrm{m} / \mathrm{z} 386.1572[\mathrm{M}+\mathrm{Na}]^{+}$(Calcd for $\left.\mathrm{C}_{19} \mathrm{H}_{25} \mathrm{NO}_{6} \mathrm{Na}: 386.1580\right) ;[\alpha]_{\mathrm{D}}^{23}+104.8\left(c=0.99, \mathrm{CHCl}_{3}\right) ; \mathrm{HPLC}$ conditions for 4d major: Daicel CHIRALCEL OJ-H, e: Hex$\mathrm{IPA}=50: 50, f=0.5 \mathrm{~mL} / \mathrm{min}, \mathrm{t}: 49.8$ (minor) and 60.4 (major) min. HPLC conditions for 4d minor: Daicel CHIRALCEL $\mathrm{OJ}-\mathrm{H}$, e: Hex-IPA $=50: 50, f=0.5 \mathrm{~mL} / \mathrm{min}, \mathrm{t}: 32.2$ (major) and 35.8 (minor) $\min$.

3-((1S,6S)-6-(But-3-en-1-yl)-4-((tert-butyldimethylsilyl)oxy)cyclohexa-2,4-diene-1-carbonyl)oxazolidin-2-one
Enone 4a $(123.6 \mathrm{mg}, 0.47 \mathrm{mmol})$ was dissolved in $\mathrm{CH}_{2} \mathrm{Cl}_{2}$ $(0.9 \mathrm{~mL}) . \mathrm{NEt}_{3}(183 \mu \mathrm{L}, 1.31 \mathrm{mmol})$ and TBSOTf $(129 \mu \mathrm{L}$, $0.56 \mathrm{mmol}$ ) were added successively to the solution at $0{ }^{\circ} \mathrm{C}$. After the solution was stirred for $2 \mathrm{~h}$, the reaction was quenched by the addition of aqueous saturated $\mathrm{NaHCO}_{3}$. The mixture was extracted three times with $\mathrm{CH}_{2} \mathrm{Cl}_{2}$, and the combined organic layers were washed with brine, and dried over $\mathrm{Na}_{2} \mathrm{SO}_{4}$. After the volatile materials were removed under reduced pressure, the resulting residue was purified by column chromatography $\left(\mathrm{SiO}_{2}\right.$, hexane-AcOEt $\left.=2: 1\right)$ to give 7a $(158.7 \mathrm{mg}, 90 \%) .{ }^{1} \mathrm{H}-\mathrm{NMR}\left(400 \mathrm{MHz}, \mathrm{CDCl}_{3}\right) \delta: 0.14(6 \mathrm{H}$, s), $0.92(9 \mathrm{H}, \mathrm{s}), 1.48(1 \mathrm{H}, \mathrm{dddd}, J=6.8,10.0,10.0,15.6 \mathrm{~Hz})$, $1.55-1.64(1 \mathrm{H}, \mathrm{m}), 2.05-2.18(2 \mathrm{H}, \mathrm{m}), 2.84(1 \mathrm{H}$, dddd, $J=5.6$, 5.6, 5.6, 8.4 Hz), $4.01(2 \mathrm{H}, \mathrm{dddt}, J=7.6,10.8,10.8,10.8 \mathrm{~Hz})$, $4.21(1 \mathrm{H}, \mathrm{ddd}, J=2.0,5.6,5.6 \mathrm{~Hz}), 4.42(2 \mathrm{H}, \mathrm{t}, J=7.6 \mathrm{~Hz}), 4.92$ $(1 \mathrm{H}, \mathrm{dd}, J=2.0,4.8 \mathrm{~Hz}), 4.95(1 \mathrm{H}, \mathrm{dd}, J=1.2,10.4 \mathrm{~Hz}), 5.01$ $(1 \mathrm{H}, \mathrm{ddt}, J=2.0,2.0,15.6 \mathrm{~Hz}), 5.71(1 \mathrm{H}, \mathrm{dd}, J=5.2,10.4 \mathrm{~Hz})$, $5.80(1 \mathrm{H}, \mathrm{ddt}, J=6.4,10.0,16.8 \mathrm{~Hz}), 5.83(1 \mathrm{H}, \mathrm{d}, J=10.0 \mathrm{~Hz})$; ${ }^{13} \mathrm{C}-\mathrm{NMR}\left(100 \mathrm{MHz}, \mathrm{CDCl}_{3}\right) \delta$ : $-4.5,18.0,25.7,30.8,33.7$, $34.4,42.9,43.9,62.0,106.4,114.7,123.1,128.5,138.5,146.7$, 153.2, 172.5; IR (ATR): $v$ 2928, 2857, 1774, 1698, $1654 \mathrm{~cm}^{-1}$; HR-MS (ESI) $m / z 378.2094[\mathrm{M}+\mathrm{H}]^{+}\left(\right.$Calcd for $\mathrm{C}_{20} \mathrm{H}_{32} \mathrm{NO}_{4} \mathrm{Si}$ : $378.2101) ;[\alpha]_{\mathrm{D}}^{25}+309.4\left(c=1.00, \mathrm{CHCl}_{3}\right)$.

Methyl (E)-6-((1S,6S)-3-((tert-Butyldimethylsilyl)oxy)6-(2-oxooxazolidine-3-carbonyl)cyclohexa-2,4-dien-1-yl)hex-2-enoate (7b) Enone $\mathbf{4 b}(183.4 \mathrm{mg}, 0.55 \mathrm{mmol})$ was dissolved in $\mathrm{CH}_{2} \mathrm{Cl}_{2}(1.1 \mathrm{~mL}) . \mathrm{NEt}_{3}(213 \mu \mathrm{L}, 1.53 \mathrm{mmol})$ and TBSOTf $(153 \mu \mathrm{L}, 0.66 \mathrm{mmol})$ were added successively to the solution at $0^{\circ} \mathrm{C}$. After the solution was stirred for $2 \mathrm{~h}$, the reaction was quenched by the addition of aqueous saturated $\mathrm{NaHCO}_{3}$. The mixture was extracted three times with $\mathrm{CH}_{2} \mathrm{Cl}_{2}$, and the combined organic layers were washed with brine, and dried over $\mathrm{Na}_{2} \mathrm{SO}_{4}$. After the volatile materials were removed under reduced pressure, the resulting residue was purified by column chromatography $\left(\mathrm{SiO}_{2}\right.$, hexane-AcOEt $\left.=2: 1\right)$ to give $7 \mathbf{b}(234.6 \mathrm{mg}, 95 \%)$. ${ }^{1} \mathrm{H}-\mathrm{NMR}\left(400 \mathrm{MHz}, \mathrm{CDCl}_{3}\right) \delta: 0.14$ $(6 \mathrm{H}, \mathrm{s}), 0.92(9 \mathrm{H}, \mathrm{s}), 1.36-1.61(4 \mathrm{H}, \mathrm{m}), 2.14-2.24(2 \mathrm{H}, \mathrm{m})$, 2.81-2.86 (1H, m), $3.72(3 \mathrm{H}, \mathrm{s}), 4.01(2 \mathrm{H}, \mathrm{dddt}, J=8.4,11.6$, $11.6,11.6 \mathrm{~Hz}), 4.19(1 \mathrm{H}, \mathrm{ddd}, J=2.0,5.6,5.6 \mathrm{~Hz}), 4.43(2 \mathrm{H}$, $\mathrm{dt}, J=2.0,8.4 \mathrm{~Hz}), 4.89(1 \mathrm{H}, \mathrm{dd}, J=1.6,5.2 \mathrm{~Hz}), 5.70(1 \mathrm{H}$, dd, $J=4.8,10.0 \mathrm{~Hz}), 5.81(1 \mathrm{H}, \mathrm{d}, J=15.6 \mathrm{~Hz}), 5.83(1 \mathrm{H}, \mathrm{ddd}$, $J=1.6,1.6,10.0 \mathrm{~Hz}), 6.94(1 \mathrm{H}, \mathrm{dt}, J=7.2,15.6 \mathrm{~Hz}) ;{ }^{13} \mathrm{C}-\mathrm{NMR}$ $\left(100 \mathrm{MHz}, \mathrm{CDCl}_{3}\right) \delta:-4.5,18.0,25.1,25.6,32.2,34.1,34.7$, $42.9,43.9,51.4,62.0,106.3,121.1,123.2,128.5,146.8,149.2$, 153.2, 167.1, 172.4; IR (ATR): v 2929, 2857, 1775, 1699, $1653 \mathrm{~cm}^{-1}$; HR-MS (ESI) $\mathrm{m} / z$ 472.2138 $[\mathrm{M}+\mathrm{Na}]^{+}$(Calcd for $\left.\mathrm{C}_{23} \mathrm{H}_{35} \mathrm{NO}_{6} \mathrm{SiNa}: 472.2131\right) ;[\alpha]_{\mathrm{D}}^{25}+266.2\left(c=1.00, \mathrm{CHCl}_{3}\right)$.

3-((1S,6S)-4-((tert-Butyldimethylsilyl)oxy)-6-(4-methylpent-4-en-1-yl)cyclohexa-2,4-diene-1-carbonyl)oxazolidin2-one (7c) Enone $4 \mathbf{c}(119.0 \mathrm{mg}, 0.4 \mathrm{mmol})$ was dissolved in $\mathrm{CH}_{2} \mathrm{Cl}_{2}(8.0 \mathrm{~mL}) . \mathrm{NEt}_{3}(341 \mu \mathrm{L}, 2.4 \mathrm{mmol})$ and TBSOTf $(281 \mu \mathrm{L}, 1.2 \mathrm{mmol})$ were added successively to the solution at $0^{\circ} \mathrm{C}$. After the solution was stirred for $1 \mathrm{~h}$, the reaction was quenched by the addition of aqueous saturated $\mathrm{NaHCO}_{3}$. The mixture was extracted three times with $\mathrm{CH}_{2} \mathrm{Cl}_{2}$, and the combined organic layers were washed with brine, and dried over $\mathrm{Na}_{2} \mathrm{SO}_{4}$. After the volatile materials were removed under reduced pressure, the resulting residue was roughly purified by short-pad column chromatography $\left(\mathrm{SiO}_{2}\right.$, hexane-AcOEt $\left.=2: 1\right)$ to give impure $7 \mathrm{c}(<143.6 \mathrm{mg},<89 \%)$. Compound $7 \mathrm{c}$ was rather unstable, thus $7 \mathbf{c}$ was used for the next intramolecular 
Diels-Alder reaction without further purification.

Ethyl (E)-6-((1S,6S)-3-((tert-Butyldimethylsilyl)oxy)-6(2-oxooxazolidine-3-carbonyl)cyclohexa-2,4-dien-1-yl)-3methylhex-2-enoate (7d) Enone 4d (216.9 $\mathrm{mg}, 0.60 \mathrm{mmol})$ was dissolved in $\mathrm{CH}_{2} \mathrm{Cl}_{2}(12 \mathrm{~mL}) . \mathrm{NEt}_{3}(466 \mu \mathrm{L}, 3.35 \mathrm{mmol})$ and TBSOTf $(315 \mu \mathrm{L}, 1.37 \mathrm{mmol})$ were added successively to the solution at $0^{\circ} \mathrm{C}$. After the solution was stirred for $1 \mathrm{~h}$, the reaction was quenched by the addition of aqueous saturated $\mathrm{NaHCO}_{3}$. The mixture was extracted three times with $\mathrm{CH}_{2} \mathrm{Cl}_{2}$, and the combined organic layers were washed with brine, and dried over $\mathrm{Na}_{2} \mathrm{SO}_{4}$. After the volatile materials were removed under reduced pressure, the resulting residue was roughly purified by short-pad column chromatography $\left(\mathrm{SiO}_{2}\right.$, hexane-AcOEt $=2: 1)$ to give impure $7 \mathbf{d}(<263.7 \mathrm{mg},<93 \%)$. Compound 7d was rather unstable, thus $7 \mathbf{d}$ was used for the next intramolecular Diels-Alder reaction without further purification.

3-((1S,3a $S, 4 R, 5 R, 7 \mathrm{a} R)-7-0 x 0 o c t a h y d r o-1 H-1,5-$ methanoindene-4-carbonyl)oxazolidin-2-one (11a) Diene 7a $(67.5 \mathrm{mg}, 0.2 \mathrm{mmol})$ was dissolved in toluene $(5.0 \mathrm{~mL})$, and was stirred under refluxing condition for $22 \mathrm{~h}$. After the solution was cooled to $0^{\circ} \mathrm{C}$, TFA $(77 \mu \mathrm{L}, 1.0 \mathrm{mmol})$ was added to the mixture. After the solution was stirred for $10 \mathrm{~min}$, the reaction was quenched by the addition of aqueous saturated $\mathrm{NaHCO}_{3}$. The mixture was extracted three times with AcOEt, and the combined organic layers were washed with brine, and dried over $\mathrm{Na}_{2} \mathrm{SO}_{4}$. After the volatile materials were removed under reduced pressure, the resulting residue was purified by column chromatography $\left(\mathrm{SiO}_{2}\right.$, hexane-AcOEt $\left.=3: 2\right)$ to give 11a (25.7 mg, 49\%). ${ }^{1} \mathrm{H}-\mathrm{NMR}\left(400 \mathrm{MHz}, \mathrm{CDCl}_{3}\right) \delta: 1.55-1.66(3 \mathrm{H}$, m), 1.90-2.02 (4H, m), $2.07(1 \mathrm{H}, \mathrm{ddd}, J=2.4,2.4,18.8 \mathrm{~Hz})$, $2.23(1 \mathrm{H}, \mathrm{dd}, J=4.4,4.4 \mathrm{~Hz}), 2.40-2.46(2 \mathrm{H}, \mathrm{m}), 2.92(1 \mathrm{H}$, s), $3.61(1 \mathrm{H}, \mathrm{s}), 3.96-4.10(2 \mathrm{H}, \mathrm{m}), 4.42(2 \mathrm{H}, \mathrm{t}, J=8.0 \mathrm{~Hz})$; ${ }^{13} \mathrm{C}-\mathrm{NMR}\left(100 \mathrm{MHz}, \mathrm{CDCl}_{3}\right) \delta: 29.0,32.5,33.5,35.0,36.4$, $38.5,39.2,42.9,54.1,62.0,153.1,174.5,215.4$; IR (ATR): $v$ 2944, 2871, 1766, 1718, $1681 \mathrm{~cm}^{-1}$; HR-MS (ESI) $\mathrm{m} / z 286.1056$ $[\mathrm{M}+\mathrm{Na}]^{+}\left(\mathrm{Calcd}\right.$ for $\left.\mathrm{C}_{14} \mathrm{H}_{17} \mathrm{NO}_{4} \mathrm{Na}: 286.1055\right) ; \quad[\alpha]_{\mathrm{D}}^{26}+26.0$ $\left(c=1.00, \mathrm{CHCl}_{3}\right)$.

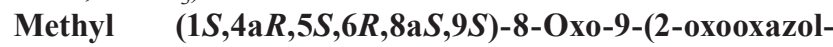
idine-3-carbonyl)decahydro-1,6-methanonaphthalene5-carboxylate (11b) Diene $\mathbf{7 b}(89.9 \mathrm{mg}, 0.2 \mathrm{mmol})$ was dissolved in toluene $(5.0 \mathrm{~mL})$, and was stirred under refluxing condition for $6 \mathrm{~h}$. After the solution was cooled to $-78^{\circ} \mathrm{C}$, $\mathrm{BF}_{3} \cdot \mathrm{OEt}_{2}(123 \mu \mathrm{L}, 1.0 \mathrm{mmol})$ was added to the mixture. After the solution was stirred for $10 \mathrm{~min}$, the reaction was quenched by the addition of aqueous saturated $\mathrm{NaHCO}_{3}$. The mixture was extracted three times with AcOEt, and the combined organic layers were washed with brine, and dried over $\mathrm{Na}_{2} \mathrm{SO}_{4}$. After the volatile materials were removed under reduced pressure, the resulting residue was purified by column chromatography $\left(\mathrm{SiO}_{2}\right.$, hexane-AcOEt $\left.=3: 2\right)$ to give $\mathbf{1 1 b}(49.3 \mathrm{mg}, 73 \%)$. ${ }^{1} \mathrm{H}-\mathrm{NMR}\left(400 \mathrm{MHz}, \mathrm{CDCl}_{3}\right) \delta: 1.42-1.74(7 \mathrm{H}, \mathrm{m}), 2.05(1 \mathrm{H}$, d, $J=20.0 \mathrm{~Hz}), 2.17-1.22(2 \mathrm{H}, \mathrm{m}), 2.57(1 \mathrm{H}, \mathrm{s}), 2.73(1 \mathrm{H}, \mathrm{s})$, $2.77(1 \mathrm{H}, \mathrm{s}), 2.91(1 \mathrm{H}, \mathrm{s}), 3.69(3 \mathrm{H}, \mathrm{s}), 3.91(1 \mathrm{H}, \mathrm{s}), 3.97-4.12$ $(2 \mathrm{H}, \mathrm{m}), 4.45(2 \mathrm{H}, \mathrm{t}, J=8.0 \mathrm{~Hz}) ;{ }^{13} \mathrm{C}-\mathrm{NMR}\left(100 \mathrm{MHz}, \mathrm{CDCl}_{3}\right)$ $\delta: 15.3,28.2,28.3,28.5,30.3,33.9,34.9,43.0,44.0,45.2,51.4$, 52.1, 62.0, 153.3, 173.7, 173.9, 213.3; IR (ATR): $v$ 2936, 1774, 1719, $1677 \mathrm{~cm}^{-1}$; HR-MS (ESI) $\mathrm{m} / z 336.1444[\mathrm{M}+\mathrm{H}]^{+}$(Calcd for $\left.\mathrm{C}_{17} \mathrm{H}_{22} \mathrm{NO}_{6}: 336.1447\right) ;[\alpha]_{\mathrm{D}}^{26}+29.1\left(c=1.02, \mathrm{CHCl}_{3}\right)$.

3-((1S,4a $S, 5 R, 6 R, 8$ a $S)-1-M e t h y l-8-o x o d e c a h y d r o-1,6-$ methanonaphthalene-5-carbonyl)oxazolidin-2-one
Diene $7 \mathrm{c}(140.0 \mathrm{mg}, 0.35 \mathrm{mmol})$ was dissolved in toluene $(6.9 \mathrm{~mL})$, and BHT $(7.6 \mathrm{mg}, 34.5 \mu \mathrm{mol})$ was added to the solution. The solution was stirred at $165^{\circ} \mathrm{C}$ (in a sealed tube) for $88 \mathrm{~h}$. After toluene was evaporated under reduced pressure, $\mathrm{CH}_{2} \mathrm{Cl}_{2}(3.3 \mathrm{~mL})$ and TFA $(49 \mu \mathrm{L}, 0.66 \mathrm{mmol})$ were added to the mixture. After stirred for $5 \mathrm{~min}$, the reaction was quenched by the addition of aqueous saturated $\mathrm{NaHCO}_{3}$. The mixture was extracted three times with AcOEt, and the combined organic layers were washed with brine, and dried over $\mathrm{Na}_{2} \mathrm{SO}_{4}$. After the volatile materials were removed under reduced pressure, the resulting residue was purified by column chromatography $\left(\mathrm{SiO}_{2}\right.$, hexane-AcOEt $\left.=1: 1\right)$ to give 11c $(60.4 \mathrm{mg}$, $53 \%$ from 4c). ${ }^{1} \mathrm{H}-\mathrm{NMR}\left(400 \mathrm{MHz}, \mathrm{CDCl}_{3}\right) \delta: 0.90(3 \mathrm{H}, \mathrm{s})$, $1.12(1 \mathrm{H}$, ddd, $J=4.8,13.6,13.6 \mathrm{~Hz}), 1.36(1 \mathrm{H}$, dddd, $J=4.4$, $4.4,14.4,14.4 \mathrm{~Hz}), 1.40(1 \mathrm{H}, \mathrm{dd}, J=2.8,14.0 \mathrm{~Hz}), 1.46-1.61$ $(3 \mathrm{H}, \mathrm{m}), 1.71(1 \mathrm{H}$, dddd, $J=4.4,4.4,13.6,13.6 \mathrm{~Hz}), 1.85(1 \mathrm{H}, \mathrm{d}$, $J=2.8 \mathrm{~Hz}), 1.89$ (1H, ddd, $J=3.2,3.2,13.6 \mathrm{~Hz}), 1.93(1 \mathrm{H}$, dddd, $J=1.2,1.2,1.2,18.0 \mathrm{~Hz}), 2.12(1 \mathrm{H}, \mathrm{ddd}, J=3.2,3.2,19.2 \mathrm{~Hz})$, $2.53(1 \mathrm{H}$, dddd, $J=2.8,2.8,2.8,2.8 \mathrm{~Hz}), 2.79(1 \mathrm{H}, \mathrm{dd}, J=3.6$, $3.6 \mathrm{~Hz}), 3.78(1 \mathrm{H}, \mathrm{dd}, J=2.8,2.8 \mathrm{~Hz}), 3.97-4.10(2 \mathrm{H}, \mathrm{m}), 4.43$ $(2 \mathrm{H}, \mathrm{t}, J=8.0 \mathrm{~Hz}) ;{ }^{13} \mathrm{C}-\mathrm{NMR}\left(100 \mathrm{MHz}, \mathrm{CDCl}_{3}\right) \delta: 17.5,28.4$, $30.17,30.22,31.98,32.04,37.9,38.1,38.4,43.0,43.5,57.4$, 61.9, 153.3, 174.6, 214.8; IR (ATR): $v$ 2925, 2867, 1773, 1716, $1691 \mathrm{~cm}^{-1}$; HR-MS (ESI) $\mathrm{m} / z 314.1361[\mathrm{M}+\mathrm{Na}]^{+}$(Calcd for $\left.\mathrm{C}_{16} \mathrm{H}_{21} \mathrm{NO}_{4} \mathrm{Na}: 314.1368\right) ;[\alpha]_{\mathrm{D}}^{21}+6.98\left(c=1.00, \mathrm{CHCl}_{3}\right)$.

Ethyl (1S,4aR,5R,6R,8aS,9S)-4a-Methyl-8-oxo-9-(2-0xooxazolidine-3-carbonyl)decahydro-1,6-methanonaphthalene-5-carboxylate (11d) Diene $7 \mathbf{d}(148.3 \mathrm{mg}, 0.31 \mathrm{mmol})$ was dissolved in toluene $(6.0 \mathrm{~mL})$, and BHT $(6.8 \mathrm{mg}, 31 \mu \mathrm{mol})$ was added to the solution. The solution was stirred at $165^{\circ} \mathrm{C}$ (in a sealed tube) for $45 \mathrm{~h}$. After toluene was evaporated under reduced pressure, $\mathrm{CH}_{2} \mathrm{Cl}_{2}(3.1 \mathrm{~mL})$ and TFA $(46 \mu \mathrm{L}, 0.62 \mathrm{mmol})$ were added to the mixture. After stirred for $5 \mathrm{~min}$, the reaction was quenched by the addition of aqueous saturated $\mathrm{NaHCO}_{3}$. The mixture was extracted three times with AcOEt, and the combined organic layers were washed with brine, and dried over $\mathrm{Na}_{2} \mathrm{SO}_{4}$. After the volatile materials were removed under reduced pressure, the resulting residue was purified by column chromatography $\left(\mathrm{SiO}_{2}\right.$, hexane-AcOEt=1:1) to give 11d $\left(67.5 \mathrm{mg}, 56 \%\right.$ from 4d). ${ }^{1} \mathrm{H}-\mathrm{NMR}\left(400 \mathrm{MHz}, \mathrm{CDCl}_{3}\right) \delta$ : $0.90(3 \mathrm{H}, \mathrm{s}), 1.16-1.22(1 \mathrm{H}, \mathrm{m}), 1.27(3 \mathrm{H}, \mathrm{t}, J=7.2 \mathrm{~Hz}), 1.43$ $(1 \mathrm{H}, \mathrm{dt}, J=4.0,12.8 \mathrm{~Hz}), 1.52(1 \mathrm{H}, \mathrm{d}, J=4.4 \mathrm{~Hz}), 1.64-1.70(1 \mathrm{H}$, m), $1.80(2 \mathrm{H}, \mathrm{d}, J=11.2 \mathrm{~Hz}), 1.86(1 \mathrm{H}, \mathrm{d}, J=2.8 \mathrm{~Hz}), 2.00(1 \mathrm{H}$, $\mathrm{dt}, J=2.8,19.6 \mathrm{~Hz}), 2.73(1 \mathrm{H}, \mathrm{t}, J=2.0 \mathrm{~Hz}), 2.82-2.84(2 \mathrm{H}, \mathrm{m})$, $2.94(1 \mathrm{H}, \mathrm{d}, J=19.6 \mathrm{~Hz}), 3.74(1 \mathrm{H}, \mathrm{s}), 3.97-4.09(2 \mathrm{H}, \mathrm{m}), 4.12$ $(2 \mathrm{H}, \mathrm{q}, J=7.2 \mathrm{~Hz}), 4.43(2 \mathrm{H}, \mathrm{t}, J=8.0 \mathrm{~Hz}) ;{ }^{13} \mathrm{C}-\mathrm{NMR}(100 \mathrm{MHz}$, $\left.\mathrm{CDCl}_{3}\right) \delta: 14.2,17.2,26.0,28.0,29.9,33.9,34.0,34.3,37.5$, 43.0, 44.8, 47.0, 59.0, 60.3, 62.0, 153.3, 173.0, 173.5, 214.0; IR (ATR): $v$ 2929, 1771, 1719, $1691 \mathrm{~cm}^{-1}$; HR-MS (ESI) $\mathrm{m} / \mathrm{z}$ $386.1576[\mathrm{M}+\mathrm{Na}]^{+}\left(\right.$Calcd for $\mathrm{C}_{19} \mathrm{H}_{25} \mathrm{NO}_{6} \mathrm{Na}$ : 386.1580); $[\alpha]_{\mathrm{D}}^{21}$ $+29.1\left(c=0.99, \mathrm{CHCl}_{3}\right)$.

3-((1S,6S)-4-((tert-Butyldimethylsilyl)oxy)-6-methylcyclohexa-2,4-diene-1-carbonyl)oxazolidin-2-one (7e) Enone 4e $\left(\mathrm{R}=\mathrm{Me}^{3}{ }^{3} \quad 995 \mathrm{mg}, 4.46 \mathrm{mmol}, 96 \%\right.$ ee $)$ was dissolved in $\mathrm{CH}_{2} \mathrm{Cl}_{2}(8.9 \mathrm{~mL}) . \mathrm{NEt}_{3}(3.5 \mathrm{~mL}, 25 \mathrm{mmol})$ and TBSOTf $(2.4 \mathrm{~mL}, 10.3 \mathrm{mmol})$ were added successively to the solution at $-10^{\circ} \mathrm{C}$. After the solution was stirred for $2 \mathrm{~h}$, the reaction was quenched by the addition of aqueous saturated $\mathrm{NaHCO}_{3}$. The mixture was extracted three times with $\mathrm{CH}_{2} \mathrm{Cl}_{2}$, and the combined organic layers were washed with brine, and dried over $\mathrm{Na}_{2} \mathrm{SO}_{4}$. After the volatile materials were removed under re- 
duced pressure, the resulting residue was roughly purified by short-pad column chromatography $\left(\mathrm{SiO}_{2}\right.$, hexane-AcOEt=2:1) to give impure $7 \mathrm{e}(<1.5 \mathrm{~g},<99 \%)$.

$3-((1 R, 4 R, 5 R, 6 R)-8-(($ tert-Butyld imethylsilyl)oxy)5-methyl-3-phenyl-2-oxa-3-azabicyclo[2.2.2]oct-7-ene6-carbonyl)oxazolidin-2-one (12 Major) To a solution of $7 \mathbf{e}(122.4 \mathrm{mg}, 0.36 \mathrm{mmol})$ in hexane $(3.6 \mathrm{~mL})$ was added nitrosobenzene $(47 \mathrm{mg}, 0.44 \mathrm{mmol})$. The mixture was stirred for overnight at $40^{\circ} \mathrm{C}$. After the volatile material was removed under reduced pressure, the resulting residue was purified by column chromatography $\left(\mathrm{SiO}_{2}\right.$, hexane- $\left.\mathrm{Et}_{2} \mathrm{O}=1: 1\right)$ to give 12 major (126.4 mg, 79\%) as a yellow solid and 12 minor $(17.6 \mathrm{mg}, 11 \%)$ as a yellow oil. ${ }^{1} \mathrm{H}-\mathrm{NMR}\left(\mathrm{CDCl}_{3}, 400 \mathrm{~Hz}\right)$ $\delta:-0.25(3 \mathrm{H}, \mathrm{s}),-0.01(3 \mathrm{H}, \mathrm{s}), 0.75(9 \mathrm{H}, \mathrm{s}), 1.35(3 \mathrm{H}, \mathrm{d}$, $J=6.8 \mathrm{~Hz}), 2.78-2.80(1 \mathrm{H}, \mathrm{m}), 3.86(1 \mathrm{H}, \mathrm{dd}, J=4.0,4.0 \mathrm{~Hz})$, 3.91-3.95 (1H, m), 4.00-4.05 (1H, m), 4.06-4.10 (1H, m), 4.43 $(2 \mathrm{H}, \mathrm{t}, J=8.4 \mathrm{~Hz}), 4.79(1 \mathrm{H}, \mathrm{dd}, J=2.4,6.4 \mathrm{~Hz}), 5.13-5.15(1 \mathrm{H}$, m), $6.88(1 \mathrm{H}, \mathrm{t}, J=7.6 \mathrm{~Hz}), 7.00(2 \mathrm{H}, \mathrm{d}, J=7.6 \mathrm{~Hz}), 7.17(2 \mathrm{H}, \mathrm{t}$, $J=4.8 \mathrm{~Hz}) ;{ }^{13} \mathrm{C}-\mathrm{NMR}\left(\mathrm{CDCl}_{3}, 100 \mathrm{MHz}\right) \delta:-5.6,-4.9,17.7$, $18.0,25.3,30.1,43.0,50.8,62.0,66.7,72.9,73.0,94.8,117.1$, 121.7, 128.2, 152.3, 153.1, 155.0, 170.9; IR (ATR): $v$ 1776, 1766, 1703, $1636 \mathrm{~cm}^{-1}$; HR-MS (ESI) $\mathrm{m} / z 467.1968[\mathrm{M}+\mathrm{Na}]^{+}(\mathrm{Calcd}$ for $\mathrm{C}_{23} \mathrm{H}_{32} \mathrm{~N}_{2} \mathrm{O}_{5} \mathrm{SiNa}$ : 467.1978); $[\alpha]_{\mathrm{D}}^{26}-17.9\left(c=1.43, \mathrm{CHCl}_{3}\right)$; HPLC conditions Daicel CHIRALPAK AD-H, e: Hex$\mathrm{IPA}=95: 5, f=1.0 \mathrm{~mL} / \mathrm{min}, \mathrm{t}: 8.5$ (minor) and 10.9 (major) $\mathrm{min}$.

3-((1S,4S,5R,6R)-8-((tert-Butyldimethylsilyl)oxy)-5-methyl-3-phenyl-2-oxa-3-azabicyclo[2.2.2]oct-7-ene-6-carbonyl)oxazolidin-2-one (12 Minor) ${ }^{1} \mathrm{H}-\mathrm{NMR}\left(\mathrm{CDCl}_{3}, 400 \mathrm{MHz}\right)$ $\delta:-0.30(3 \mathrm{H}, \mathrm{s}),-0.02(3 \mathrm{H}, \mathrm{s}), 0.73(9 \mathrm{H}, \mathrm{s}), 1.04(3 \mathrm{H}$, d, $J=7.2 \mathrm{~Hz}), 3.13(1 \mathrm{H}, \mathrm{d}, J=4.4 \mathrm{~Hz}), 3.26-3.28(1 \mathrm{H}, \mathrm{m})$, $4.07-4.13(3 \mathrm{H}, \mathrm{m}), 4.44(2 \mathrm{H}, \mathrm{t}, J=8.4 \mathrm{~Hz}), 5.03(1 \mathrm{H}, \mathrm{d}$, $J=6.8 \mathrm{~Hz}), 5.16-5.17(1 \mathrm{H}, \mathrm{m}), 6.88(1 \mathrm{H}, \mathrm{t}, J=7.6 \mathrm{~Hz}), 6.99$ $(2 \mathrm{H}, \mathrm{d}, J=7.6 \mathrm{~Hz}), 7.16(2 \mathrm{H}, \mathrm{t}, J=7.6 \mathrm{~Hz}) ;{ }^{13} \mathrm{C}-\mathrm{NMR}\left(\mathrm{CDCl}_{3}\right.$, $100 \mathrm{MHz}) \delta:-4.8,0.0,14.2,17.6,19.8,25.2,29.4,43.1,52.6$, $62.3,67.2,73.5,97.5,117.3,122.1,128.1,151.8,152.1,153.7$, 171.4; IR (ATR): $v$ 1771, 1773, 1699, $1637 \mathrm{~cm}^{-1}$; HR-MS (ESI) $m / z 467.1985[\mathrm{M}+\mathrm{Na}]^{+}$(Calcd for $\mathrm{C}_{23} \mathrm{H}_{32} \mathrm{~N}_{2} \mathrm{O}_{5} \mathrm{SiNa}$ : 467.1978); $[\alpha]_{\mathrm{D}}^{26}+78.4\left(c=1.15, \mathrm{CHCl}_{3}\right)$.

((1S,6R)-4-((tert-Butyldimethylsilyl)oxy)-6-methylcyclohexa-2,4-dien-1-yl)methanol (13) To a solution of $7 \mathrm{e}$ $(139 \mathrm{mg}, 0.41 \mathrm{mmol})$ in tetrahydrofuran (THF) was added lithium borohydride $(13.4 \mathrm{mg}, 0.61 \mathrm{mmol})$ and methanol $(24.7 \mu \mathrm{L}$, $0.61 \mathrm{mmol}$ ) at $0^{\circ} \mathrm{C}$. The mixture was stirred for $1 \mathrm{~h}$ at room temperature. The reaction was quenched by the addition of water. The mixture was extracted three times with AcOEt, and the combined organic layers were washed with brine, and dried over $\mathrm{Na}_{2} \mathrm{SO}_{4}$. After the volatile materials were removed under reduced pressure, the resulting residue was purified by column chromatography $\left(\mathrm{SiO}_{2}\right.$, hexane-AcOEt $\left.=2: 1\right)$ to give $13(92.7 \mathrm{mg}, 89 \%) .{ }^{1} \mathrm{H}-\mathrm{NMR}\left(\mathrm{CDCl}_{3}, 400 \mathrm{MHz}\right) \delta: 0.12(3 \mathrm{H}$, s), $0.13(3 \mathrm{H}, \mathrm{s}), 0.92(9 \mathrm{H}, \mathrm{s}), 1.02(3 \mathrm{H}, \mathrm{d}, J=7.2 \mathrm{~Hz}), 1.59(1 \mathrm{H}$, brs), 2.13-2.18 (1H, m), 2.39-2.46 (1H, m), 3.52-3.59 (2H, m), $4.77(1 \mathrm{H}, \mathrm{dd}, J=1.6,5.2 \mathrm{~Hz}), 5.70(1 \mathrm{H}, \mathrm{dd}, J=4.4,10.0 \mathrm{~Hz}), 5.75$ $(1 \mathrm{H}, \mathrm{dd}, J=0.8,9.6 \mathrm{~Hz}) ;{ }^{13} \mathrm{C}-\mathrm{NMR}\left(\mathrm{CDCl}_{3}, 100 \mathrm{MHz}\right) \delta:-4.5$, 18.0, 20.3, 25.7, 29.3, 43.4, 64.1, 108.2, 126.9, 128.0, 146.6; IR (ATR): $v$ 1771, 1773, 1699, $1637 \mathrm{~cm}^{-1}$; HR-MS (ESI) $\mathrm{m} / \mathrm{z}$ 277.1585 [M+Na] ${ }^{+}$(Calcd for $\mathrm{C}_{14} \mathrm{H}_{26} \mathrm{O}_{2} \mathrm{SiNa}$ : 277.1599).

$((1 R, 4 S, 5 R, 6 S)-8-(($ tert-Butyldimethylsilyl)oxy)-5-methyl3-phenyl-2-oxa-3-azabicyclo[2.2.2]oct-7-en-6-yl)methanol (14 Major) To a solution of $\mathbf{1 3}(92.7 \mathrm{mg}, 0.36 \mathrm{mmol})$ in hexane $(7.2 \mathrm{~mL})$ was added nitrosobenzene $(57.8 \mathrm{mg}, 0.54 \mathrm{mmol})$.
The mixture was stirred for $1 \mathrm{~h}$ at room temperature. After the volatile material was removed under reduced pressure, the resulting residue was purified by column chromatography $\left(\mathrm{SiO}_{2}\right.$, hexane- $\left.\mathrm{Et}_{2} \mathrm{O}=1: 1\right)$ to give $\mathbf{1 4}$ major $(98.9 \mathrm{mg}, 76 \%)$ as a yellow solid and $\mathbf{1 4}$ minor $(11.7 \mathrm{mg}, 9 \%)$ as a yellow oil. ${ }^{1} \mathrm{H}-\mathrm{NMR}$ $\left(\mathrm{CDCl}_{3}, 400 \mathrm{MHz}\right) \delta$ : $-0.29(3 \mathrm{H}, \mathrm{s}), 0.0(3 \mathrm{H}, \mathrm{s}), 0.73(9 \mathrm{H}, \mathrm{s})$, $1.02(3 \mathrm{H}, \mathrm{d}, J=7.6 \mathrm{~Hz}), 1.23-1.27(1 \mathrm{H}, \mathrm{m}), 1.95-2.00(1 \mathrm{H}, \mathrm{m})$, $2.36(1 \mathrm{H}, \mathrm{brs}), 3.82(2 \mathrm{H}, \mathrm{d}, J=6.0 \mathrm{~Hz}), 3.97(1 \mathrm{H}, \mathrm{t}, J=2.8 \mathrm{~Hz})$, $4.76(1 \mathrm{H}, \mathrm{d}, J=6.8 \mathrm{~Hz}), 5.13(1 \mathrm{H}, \mathrm{dd}, J=2.4,6.8 \mathrm{~Hz}), 6.88(1 \mathrm{H}$, $\mathrm{t}, J=7.2 \mathrm{~Hz}), 7.02(2 \mathrm{H}, \mathrm{d}, J=7.6 \mathrm{~Hz}), 7.17(2 \mathrm{H}, \mathrm{t}, J=7.2 \mathrm{~Hz})$; ${ }^{13} \mathrm{C}-\mathrm{NMR}\left(\mathrm{CDCl}_{3}, 100 \mathrm{MHz}\right) \delta:-5.7,-4.9,13.9,17.6,19.7$, $25.2,31.0,48.3,63.3,67.7,73.0,98.7,117.3,122.0,128.2$, 151.3, 152.0; IR (ATR): $v$ 1737, 1364, $1216 \mathrm{~cm}^{-1}$; HR-MS (ESI) $m / z$ 384.1984 [M+Na] ${ }^{+}$(Calcd for $\mathrm{C}_{20} \mathrm{H}_{31} \mathrm{NO}_{3} \mathrm{SiNa}$ : 384.1970); $[\alpha]_{\mathrm{D}}^{26}+111.5\left(c=1.15, \mathrm{CHCl}_{3}\right)$.

((1S,4R,5R,6S)-8-((tert-Butyldimethylsilyl)oxy)-5-methyl3-phenyl-2-oxa-3-azabicyclo[2.2.2]oct-7-en-6-yl)methanol (14 Minor) ${ }^{1} \mathrm{H}-\mathrm{NMR}\left(\mathrm{CDCl}_{3}, 400 \mathrm{MHz}\right) \delta$ : $-0.25(3 \mathrm{H}, \mathrm{s})$, $0.01(3 \mathrm{H}, \mathrm{s}), 0.74(9 \mathrm{H}, \mathrm{s}), 1.38(3 \mathrm{H}, \mathrm{d}, J=6.8 \mathrm{~Hz}), 1.47-1.53$ $(1 \mathrm{H}, \mathrm{m}), 1.96-2.01(1 \mathrm{H}, \mathrm{m}), 3.29(1 \mathrm{H}, \mathrm{t}, J=9.6 \mathrm{~Hz}), 3.45(1 \mathrm{H}$, $\mathrm{dd}, J=5.6,10.8 \mathrm{~Hz}), 3.93(1 \mathrm{H}, \mathrm{s}), 4.84(1 \mathrm{H}, \mathrm{dd}, J=3.6,6.8 \mathrm{~Hz})$, $5.02(1 \mathrm{H}, \mathrm{dd}, J=2.4,6.8 \mathrm{~Hz}), 6.86(1 \mathrm{H}, \mathrm{t}, J=7.2 \mathrm{~Hz}), 7.01$ $(2 \mathrm{H}, \mathrm{d}, J=8.0 \mathrm{~Hz}), 7.17(2 \mathrm{H}, \mathrm{t}, J=7.2 \mathrm{~Hz}) ;{ }^{13} \mathrm{C}-\mathrm{NMR}\left(\mathrm{CDCl}_{3}\right.$, $100 \mathrm{MHz}) \delta:-5.7,-4.7,17.7,18.0,25.3,31.9,48.3,63.3,59.2$, $65.2,67.3,73.5,96.0,117.2,121.7,128.2,152.6,153$; IR (ATR): $v$ 1636, 1488, 1471, $1348 \mathrm{~cm}^{-1}$; HR-MS (ESI) $\mathrm{m} / \mathrm{z} 384.1931$ $[\mathrm{M}+\mathrm{Na}]^{+}\left(\right.$Calcd for $\mathrm{C}_{20} \mathrm{H}_{31} \mathrm{NO}_{3} \mathrm{SiNa}$ : 384.1970); $[\alpha]_{\mathrm{D}}^{26}-14.29$ $\left(c=0.87, \mathrm{CHCl}_{3}\right)$.

3-((1R,2R,5R,6R)-4-((tert-Butyldimethylsilyl)oxy)-2-hydroxy-6-methyl-5-(phenylamino)cyclohex-3-enecarbonyl)oxazolidin-2-one (15) To a solution of 12 major (50 mg, $0.11 \mathrm{mmol})$ in isopropanol $(5 \mathrm{~mL})$ was added $\mathrm{Pd}(\mathrm{OH})_{2} / \mathrm{C}$ $(10 \%(\mathrm{w} / \mathrm{w}))$. The slurry was stirred for overnight at room temperature under hydrogen atmosphere. The insoluble materials were filtered through a pad of Celite ${ }^{\circledR}$, and washed with AcOEt. After the volatile material was removed under reduced pressure, the resulting residue was purified by column chromatography $\left(\mathrm{SiO}_{2}\right.$, hexane-AcOEt=1:1) to give $\mathbf{1 5}$ (51 mg, quant.). ${ }^{1} \mathrm{H}-\mathrm{NMR}\left(\mathrm{CDCl}_{3}, 400 \mathrm{~Hz}\right) \delta: 0.08(3 \mathrm{H}, \mathrm{s}), 0.13$ $(3 \mathrm{H}, \mathrm{s}), 0.76(9 \mathrm{H}, \mathrm{s}), 0.95(3 \mathrm{H}, \mathrm{d}, J=6.8 \mathrm{~Hz}), 2.15-2.19(1 \mathrm{H}$, m), $3.71(1 \mathrm{H}, \mathrm{d}, J=3.2 \mathrm{~Hz}), 3.94-3.98(2 \mathrm{H}, \mathrm{m}), 4.0-4.07(1 \mathrm{H}$, m), $4.32(2 \mathrm{H}, \mathrm{t}, J=8.4 \mathrm{~Hz}), 4.45-4.47(1 \mathrm{H}, \mathrm{d}, J=9.2 \mathrm{~Hz}), 4.83$ $(1 \mathrm{H}, \mathrm{d}, J=2.4 \mathrm{~Hz}), 6.54-6.65(3 \mathrm{H}, \mathrm{m}), 7.03(2 \mathrm{H}, \mathrm{t}, J=8.0 \mathrm{~Hz})$; ${ }^{13} \mathrm{C}-\mathrm{NMR}\left(\mathrm{CDCl}_{3}, 100 \mathrm{MHz}\right) \delta:-4.7,-4.5,14.7,25.3,36.3$, 42.8, 48.0, 56.6, 61.9, 70.9, 107.6, 113.3, 117.3, 129.0, 149.0, $153.5,175.1$; IR (ATR): $v 1767,1669,1651,1599 \mathrm{~cm}^{-1}$; HR-MS (ESI) $m / z$ 469.2102 $[\mathrm{M}+\mathrm{Na}]^{+}$(Calcd for $\mathrm{C}_{23} \mathrm{H}_{34} \mathrm{~N}_{2} \mathrm{O}_{5} \mathrm{SiNa}$ : 469.2135); $[\alpha]_{\mathrm{D}}^{26}+40.9\left(c=0.98, \mathrm{CHCl}_{3}\right) ;$ HPLC conditions Daicel CHIRALPAK IA, e: Hex-IPA $=75: 25, f=1.0 \mathrm{~mL} / \mathrm{min}$, t: 5.3 (minor) and 6.7 (major) min.

3-((1R,2S,3S,5R,6R)-3-((tert-Butyldimethylsilyl)oxy)-2hydroxy-6-methyl-4-oxo-5-(phenylamino)cyclohexanecarbonyl)oxazolidin-2-one (16) To a solution of $\mathbf{1 5}(113 \mathrm{mg}$, $0.25 \mathrm{mmol})$ in $\mathrm{CH}_{2} \mathrm{Cl}_{2}(10 \mathrm{~mL})$ was added aqueous saturated $\mathrm{NaHCO}_{3}(2.0 \mathrm{~mL})$, then added $m$-chloroperbenzoic acid (mCPBA) (max. $77 \%, 84 \mathrm{mg}, 0.38 \mathrm{mmol})$ at $0^{\circ} \mathrm{C}$. The slurry was stirred for $2 \mathrm{~h}$ with increasing the reaction temperature from $0^{\circ} \mathrm{C}$ to room temperature. Aqueous saturated $\mathrm{NaHCO}_{3}$ was then added, and the water layer was extracted three times with $\mathrm{CH}_{2} \mathrm{Cl}_{2}$, then the combined organic layers were washed with brine, and dried over $\mathrm{Na}_{2} \mathrm{SO}_{4}$. After the volatile 
material was removed under reduced pressure. The resulting residue was purified by column chromatography $\left(\mathrm{SiO}_{2}\right.$, hexane-AcOEt $=2: 1)$ to give $16(67 \mathrm{mg}, 58 \%) .{ }^{1} \mathrm{H}-\mathrm{NMR}\left(\mathrm{CDCl}_{3}\right.$, $400 \mathrm{MHz}) \delta: 0.07(3 \mathrm{H}, \mathrm{s}), 0.17(3 \mathrm{H}, \mathrm{s}), 0.94(9 \mathrm{H}, \mathrm{s}), 1.13(3 \mathrm{H}$, d, $J=7.2 \mathrm{~Hz}), 2.87-2.91(1 \mathrm{H}, \mathrm{m}), 2.98(1 \mathrm{H}, \mathrm{s}), 4.12-4.16(2 \mathrm{H}$, $\mathrm{m}), 4.41(1 \mathrm{H}, \mathrm{t}, J=2.0,4.4 \mathrm{~Hz}), 4.46-4.47(1 \mathrm{H}, \mathrm{m}), 4.47(2 \mathrm{H}, \mathrm{t}$, $J=8.0 \mathrm{~Hz}), 4.59(1 \mathrm{H}$, brt, $J=5.6 \mathrm{~Hz}), 4.72(1 \mathrm{H}$, brd, $J=6.4 \mathrm{~Hz})$, $4.88(1 \mathrm{H}, \mathrm{d}, J=4.8 \mathrm{~Hz}), 6.54(2 \mathrm{H}, \mathrm{d}, J=8.0 \mathrm{~Hz}), 6.70(1 \mathrm{H}, \mathrm{t}$, $J=7.6 \mathrm{~Hz}), 7.15(1 \mathrm{H}, \mathrm{t}, J=7.6 \mathrm{~Hz}) ;{ }^{13} \mathrm{C}-\mathrm{NMR}\left(\mathrm{CDCl}_{3}, 150 \mathrm{MHz}\right)$ $\delta:-5.4,-4.6,14.7,18.4,25.7,38.5,42.7,47.1,59.9,62.0,112.9$, $117.7,129.3,145.9,152.9,173.8,204.9$; IR (ATR): $v 1770$, 1740, 1685, 1205, 835, $748 \mathrm{~cm}^{-1}$; HR-MS (ESI) $\mathrm{m} / \mathrm{z} 485.2089$ $[\mathrm{M}+\mathrm{Na}]^{+}$(Calcd for $\left.\mathrm{C}_{23} \mathrm{H}_{34} \mathrm{~N}_{2} \mathrm{O}_{6} \mathrm{SiNa}: 485.2083\right) ;[\alpha]_{\mathrm{D}}^{26}-9.6$ $\left(c=0.51, \mathrm{CHCl}_{3}\right) ; \mathrm{HPLC}$ conditions Daicel CHIRALPAK $\mathrm{AD}-\mathrm{H}$, e: Hex-IPA $=70: 30, f=0.7 \mathrm{~mL} / \mathrm{min}, \mathrm{t}: 16.3$ (major) and 26.8 (minor) $\min$.

3-((1R,2S,3S,5R,6R)-2,3-Dihydroxy-6-methyl-4-oxo-5(phenylamino)cyclohexanecarbonyl)oxazolidin-2-one (17) To a solution of $\mathbf{1 6}(30.0 \mathrm{mg}, 64.8 \mu \mathrm{mol})$ in THF $(3.2 \mathrm{~mL})$ was added $\mathrm{AcOH}(1 \mathrm{~m}$ in $\mathrm{THF}, 65 \mu \mathrm{L})$ and tetrabutylammonium fluoride (TBAF) $(1 \mathrm{M}$ in $\mathrm{THF}, 97 \mu \mathrm{L})$ at $-78^{\circ} \mathrm{C}$. The resulting mixture was stirred for $3 \mathrm{~h}$ with increasing the reaction temperature from -78 to $0^{\circ} \mathrm{C}$. Water was then added, and the water layer was extracted three times with AcOEt, then the combined organic layers were dried over $\mathrm{Na}_{2} \mathrm{SO}_{4}$. After the volatile material was removed under reduced pressure, the resulting residue was purified by column chromatography $\left(\mathrm{SiO}_{2}\right.$, hexane-AcOEt=1:1) to give $17(14.8 \mathrm{mg}, 66 \%)$. ${ }^{1} \mathrm{H}-\mathrm{NMR}$ (dimethyl sulfoxide (DMSO)- $\left.d_{6}, 400 \mathrm{MHz}, 55^{\circ} \mathrm{C}\right) \delta$ : $1.01(3 \mathrm{H}$, brd, $J=6.8 \mathrm{~Hz}), 2.82(1 \mathrm{H}, \mathrm{brt}, J=6.8 \mathrm{~Hz}), 4.01(2 \mathrm{H}, \mathrm{t}$, $J=4.8 \mathrm{~Hz}), 4.12(1 \mathrm{H}, \mathrm{brs}), 4.40(3 \mathrm{H}, \mathrm{brt}, J=7.6 \mathrm{~Hz}), 4.62(1 \mathrm{H}$, brs), 4.69 (1H, t, $J=7.6 \mathrm{~Hz}), 4.90(1 \mathrm{H}$, br s), $5.12(1 \mathrm{H}$, br s), 5.43 $(1 \mathrm{H}, \mathrm{brs}), 6.55(1 \mathrm{H}, \mathrm{t}, J=6.8 \mathrm{~Hz}), 6.64(2 \mathrm{H}, \mathrm{d}, J=7.6 \mathrm{~Hz}), 7.06$ $(2 \mathrm{H}, \mathrm{t}, J=7.6 \mathrm{~Hz}) ;{ }^{13} \mathrm{C}-\mathrm{NMR}$ (DMSO- $\left.d_{6}, 100 \mathrm{MHz}, 55^{\circ} \mathrm{C}\right) \delta$ : $14.9,37.6,42.7,48.3,55.7,59.6,62.1,75.4,75.5,112.6,128.7$, 146.7, 153.2, 173.1, 175.2, 207.0. IR (ATR): $v$ 1779, 1735, 1475, 1391, $1365 \mathrm{~cm}^{-1}$; HR-MS (ESI) $\mathrm{m} / z 371.1204[\mathrm{M}+\mathrm{Na}]^{+}$ (Calcd for $\left.\mathrm{C}_{17} \mathrm{H}_{20} \mathrm{~N}_{2} \mathrm{O}_{6} \mathrm{Na}: 371.1219\right) ;[\alpha]_{\mathrm{D}}^{26}+1.8 \quad(c=0.43$, $\mathrm{MeCN})$; HPLC conditions Daicel CHIRALPAK IC, e: Hex$\mathrm{IPA}=40: 60, f=0.75 \mathrm{~mL} / \mathrm{min}, \mathrm{t}: 27.2$ (minor) and 52.0 (major) $\min$.

3-((1R,2S,3S,4R,5R,6R)-3-((tert-Butyldimethylsilyl)oxy)-2,4-dihydroxy-6-methyl-5-(phenylamino)cyclohexanecarbonyl)oxazolidin-2-one (18) To a solution of $\mathbf{1 6}$ $(41 \mathrm{mg}, 0.09 \mathrm{mmol})$ in THF $(5 \mathrm{~mL})$ was added $\mathrm{MeOH}(5.3 \mu \mathrm{L}$, $0.13 \mathrm{mmol})$ and $\mathrm{LiBH}_{4}(2 \mathrm{M}$ in THF, $65 \mu \mathrm{L}, 0.13 \mathrm{mmol})$ at $0^{\circ} \mathrm{C}$. The mixture was stirred for $20 \mathrm{~min}$ at $0^{\circ} \mathrm{C} \cdot \mathrm{H}_{2} \mathrm{O}$ was added to quench the reaction. The water layer was extracted three times with AcOEt. The combined organic layers were washed with brine, and dried over $\mathrm{Na}_{2} \mathrm{SO}_{4}$. After the volatile material was removed under reduced pressure. The resulting residue was purified by column chromatography $\left(\mathrm{SiO}_{2}\right.$, hexane-AcOEt $\left.=2: 1\right)$ to give 18 (major: $33 \mathrm{mg}, 81 \%$; minor: $2.0 \mathrm{mg}, 5 \%)$. ${ }^{1} \mathrm{H}-\mathrm{NMR}\left(\mathrm{CDCl}_{3}, 600 \mathrm{MHz}\right) \delta: 0.20$ $(6 \mathrm{H}, \mathrm{s}), 0.83(3 \mathrm{H}, \mathrm{d}, J=7.2 \mathrm{~Hz}), 1.04(9 \mathrm{H}, \mathrm{s}), 2.12-2.15(1 \mathrm{H}$, m), $2.54(1 \mathrm{H}, \mathrm{d}, J=11.4 \mathrm{~Hz}), 2.84(1 \mathrm{H}, \mathrm{d}, J=10.2 \mathrm{~Hz}), 3.64$ $(1 \mathrm{H}, \mathrm{dd}, J=3.0,6.6 \mathrm{~Hz}), 3.73(1 \mathrm{H}, \mathrm{dt}, J=1.8,10.8 \mathrm{~Hz}), 3.95$ $(1 \mathrm{H}, \mathrm{dt}, J=4.2,11.4 \mathrm{~Hz}), 4.00-4.03(1 \mathrm{H}, \mathrm{m}), 4.10-4.12(1 \mathrm{H}$, $\mathrm{m}), 4.18(1 \mathrm{H}, \mathrm{s}), 4.32(1 \mathrm{H}, \mathrm{t}, J=11.4 \mathrm{~Hz}), 4.35-4.44(3 \mathrm{H}, \mathrm{m})$, $6.66(1 \mathrm{H}, \mathrm{t}, J=7.8 \mathrm{~Hz}), 6.68(2 \mathrm{H}, \mathrm{d}, J=7.8 \mathrm{~Hz}), 7.14(2 \mathrm{H}, \mathrm{t}$, $J=7.8 \mathrm{~Hz}) ;{ }^{13} \mathrm{C}-\mathrm{NMR}\left(\mathrm{CDCl}_{3}, 150 \mathrm{MHz}\right) \delta:-4.7,-4.1,16.0$,
$18.3,25.9,26.0,37.2,42.7,43.9,57.4,61.9,69.0,73.6,76.2$, $13.2,117.6,129.3,148.9,154.2,175.3$; IR (ATR): $v 1709$, 1359, 1291, $833 \mathrm{~cm}^{-1}$; HR-MS (ESI) $\mathrm{m} / z$ 487.2220 [M+Na] ${ }^{+}$ (Calcd for $\mathrm{C}_{23} \mathrm{H}_{36} \mathrm{~N}_{2} \mathrm{O}_{6} \mathrm{SiNa}$ : 487.2240); $[\alpha]_{D}^{26}-12.1(c=1.78$, $\mathrm{CHCl}_{3}$ ); HPLC conditions Daicel CHIRALPAK IC, e: Hex$\mathrm{IPA}=90: 10, f=1.0 \mathrm{~mL} / \mathrm{min}, \mathrm{t}: 12.2$ (major) and 14.3 (minor) $\min$.

$(2 S, 3 S, 4 S, 5 R, 6 R)-2-((t e r t-B u t y l d i m e t h y l s i l y l) o x y)-4-$ (hydroxymethyl)-5-methyl-6-(phenylamino)cyclohexane-1,3-diol (19) To a solution of $16(163.5 \mathrm{mg}, 0.35 \mathrm{mmol})$ in THF $(15 \mathrm{~mL})$ was added $\mathrm{MeOH}(0.13 \mathrm{~mL}, 3.24 \mathrm{mmol})$ and $\mathrm{LiBH}_{4}(2 \mathrm{M}$ in $\mathrm{THF}, 1.6 \mathrm{~mL})$ at $0^{\circ} \mathrm{C}$. The mixture was stirred for $1 \mathrm{~h}$ at $0^{\circ} \mathrm{C} . \mathrm{H}_{2} \mathrm{O}$ was added to quench the reaction. The water layer was extracted three times with AcOEt. The combined organic layers were washed with brine, and dried over $\mathrm{Na}_{2} \mathrm{SO}_{4}$. After the volatile material was removed under reduced pressure. The resulting residue was purified by column chromatography $\left(\mathrm{SiO}_{2}\right.$, hexane-AcOEt $\left.=2: 1\right)$ to give 19 as diastereomixture (101 $\mathrm{mg}, 76 \%, \mathrm{dr}=3: 2$ (determined by $\left.{ }^{1} \mathrm{H}-\mathrm{NMR}\right)$ ). The $\mathbf{1 9}$ major could be partially isolated by recrystallization from $\mathrm{CH}_{2} \mathrm{Cl}_{2}$ and hexane. ${ }^{1} \mathrm{H}-\mathrm{NMR}\left(\mathrm{CDCl}_{3}\right.$, $600 \mathrm{MHz}) \delta:-0.14(3 \mathrm{H}, \mathrm{s}), 0.04(3 \mathrm{H}, \mathrm{s}), 0.72(9 \mathrm{H}, \mathrm{s}), 1.07$ $(3 \mathrm{H}, \mathrm{d}, J=7.2 \mathrm{~Hz}), 1.53-1.56(1 \mathrm{H}, \mathrm{m}), 1.76-1.86(1 \mathrm{H}, \mathrm{m}), 2.80$ $(1 \mathrm{H}$, brs $), 3.05(1 \mathrm{H}$, brs $), 3.36(1 \mathrm{H}$, br d, $J=7.2 \mathrm{~Hz}), 3.56(1 \mathrm{H}$, brs), 3.64-3.75 (3H, m), 4.07-4.13 (2H, m), $4.65(1 \mathrm{H}, \mathrm{brs})$, $6.61(1 \mathrm{H}, \mathrm{t}, J=7.2 \mathrm{~Hz}), 6.62(2 \mathrm{H}, \mathrm{d}, J=8.4 \mathrm{~Hz}), 7.09(2 \mathrm{H}, \mathrm{t}$, $J=7.6 \mathrm{~Hz}) ;{ }^{13} \mathrm{C}-\mathrm{NMR}\left(\mathrm{CDCl}_{3}, 150 \mathrm{MHz}\right) \delta:-5.1,-5.0,15.8$, $18.3,25.8,33.4,40.0,61.0,62.8,71.5,73.2,75.5,113.6,117.0$, 129.2, 150.9; IR (ATR): $v$ 1750, 1351, $1213 \mathrm{~cm}^{-1}$; HR-MS (ESI) $m / z$ 404.2222 $[\mathrm{M}+\mathrm{Na}]^{+}$(Calcd for $\mathrm{C}_{20} \mathrm{H}_{35} \mathrm{NO}_{4} \mathrm{SiNa}$ : 404.2233); $[\alpha]_{\mathrm{D}}^{26}-9.9\left(c=1.09, \mathrm{CHCl}_{3}\right)$; HPLC conditions Daicel CHIRALPAK IA, e: Hex-IPA $=90: 10, f=1.0 \mathrm{~mL} / \mathrm{min}$, t: 8.3 (minor) and 10.1 (major) min.

Acknowledgments This work was supported by JSPS KAKENHI (Grant Numbers 22790007, 25460006 (S. Harada), 12J04105 (S. Hiraoka), and 21390002, 25293001 (A. N.)) and by JSPS Asian Core Program. C.-H. Wu thanks Financial support by Taiwan ACP program, NSC98-2911-007-001.

Conflict of Interest The authors declare no conflict of interest.

\section{References and Notes}

1) Ishihara K., Sakakura A., "Science of Synthesis Stereoselective Synthesis," Vol. 3, Chap. 2, ed. by De Vries J. G., Molander G. A., Evans P. A., George Thieme, Stuttgart, New York, 2011, pp. 67-123.

2) Sudo Y., Shirasaki D., Harada S., Nishida A., J. Am. Chem. Soc., 130, 12588-12589 (2008).

3) Harada S., Toudou N., Hiraoka S., Nishida A., Tetrahedron Lett., 50, 5652-5655 (2009).

4) Hiraoka S., Harada S., Nishida A., J. Org. Chem., 75, 3871-3874 (2010).

5) Harada S., Ishii H., Shirasaki D., Nishida A., Heterocycles, 90 , 967-977 (2015)

6) Harada S., Morikawa T., Nishida A., Org. Lett., 15, 5314-5317 (2013).

7) Morikawa T., Harada S., Nishida A., J. Org. Chem., 80, 8859-8867 (2015).

8) Burreson B. J., Scheuer P. J., Finer J., Clardy J., J. Am. Chem. Soc., 97, 4763-4764 (1975).

9) Corey E. J., Behforouz M., Ishiguro M., J. Am. Chem. Soc., 101, 
1608-1609 (1979).

10) Yamamoto H., Sham H. L., J. Am. Chem. Soc., 101, 1609-1611 (1979).

11) Srikrishna A., Hemamalini P., Veera Raghava Sharma G., J. Org. Chem., 58, 2509-2516 (1993).

12) Chang N. C., Chang C. K., J. Org. Chem., 61, $4967-4970$ (1996).

13) Zhao F.-W., Sun Q.-Y., Yang F.-M., Hu G.-W., Luo J.-F., Tang G.-H., Wang Y.-H., Long C.-L., Org. Lett., 12, 3922-3925 (2010).

14) Zhang G.-B., Wang F.-X., Du J.-Y., Qu H., Ma X.-Y., Wei M.-X., Wang C.-T., Li Q., Fan C.-A., Org. Lett., 14, 3696-3699 (2012).

15) Sizemore N., Rychnovsky S. D., Org. Lett., 16, 688-691 (2014).

16) Tsubaki N., Nishimura K., Hirose Y., Bull. Chem. Soc. Jpn., 40, 597-600 (1967).

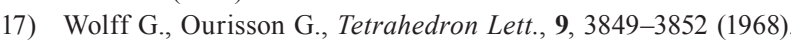

18) Srikrishna A., Ravi G., Satyanarayana G., Tetrahedron Lett., 48, 73-76 (2007)

19) Niwa H., Wakamatsu K., Hida T., Niiyama K., Kigoshi H., Yamada M., Nagase H., Suzuki M., Yamada K., J. Am. Chem. Soc., 106, 4547-4552 (1984).

20) Bhamare N. K., Granger T., John C. R., Yates P., Tetrahedron Lett., 32, 4439-4442 (1991).

21) Takasu K., Mizutani S., Ihara M., J. Org. Chem., 67, 2881-2884 (2002).

22) Singh V., Pal S., Mobin S. M., J. Org. Chem., 71, 3014-3025 (2006).

23) Murphy G. K., Shirahata T., Hama N., Bedermann A., Dong P., McMahon T. C., Twenter B. M., Spiegel D. A., McDonald I. M., Taniguchi N., Inoue M., Wood J. L., J. Org. Chem., 78, 477-489 (2013).
24) Yamamoto Y., Yamamoto H., Eur. J. Org. Chem., 2006, 2031-2043 (2006).

25) Carosso S., Miller M. J., Org. Biomol. Chem., 12, 7445-7468 (2014).

26) CCDC 1476546 contains the supplementary crystallographic data for this paper. These data can be obtained free of charge from The Cambridge Crystallographic Data Center via www.ccdc.cam.ac.uk/ data_request/cif.

27) CCDC 1476580 contains the supplementary crystallographic data for this paper. These data can be obtained free of charge from The Cambridge Crystallographic Data Center via www.ccdc.cam.ac.uk/ data_request/cif.

28) Delgado A., Eur. J. Org. Chem., 2008, 3893-3906 (2008).

29) Teoh E., Campi E. M., Jackson W. R., Robinson A. J., New J. Chem., 27, 387-394 (2003).

30) Whittaker M., McArthur C. R., Leznoff C. C., Can. J. Chem., 63, 2844-2852 (1985).

31) Knol J., Feringa B. L., Synlett, 1995, 1025-1026 (1995).

32) Brown P. M., Käppel N., Murphy P. J., Coles S. J., Hursthouse M. B., Tetrahedron, 63, 1100-1106 (2007).

33) Niwayama S., Cho H., Lin C., Tetrahedron Lett., 49, 4434-4436 (2008).

34) Ghosh A. K., Nicponski D. R., Org. Lett., 13, 4328-4331 (2011).

35) Marshall J. A., Andersen M. W., J. Org. Chem., 58, 3912-3918 (1993).

36) Dias L. C., Melgar G. Z., Jardim L. S. A., Tetrahedron Lett., 46, 4427-4431 (2005).

37) Nishida A., Kawahara N., Nishida M., Yonemitsu O., Tetrahedron, 52, 9713-9734 (1996). 